\title{
Origin of the mineralised Hawke Bay conglomerate and its importance in formation of the Vassbo lead-zinc deposit, Sweden
}

\author{
Arne Bjørlykke ${ }^{1}$, Aivo Lepland ${ }^{1} \& \varnothing$ yvind Skår $^{1}$ \\ ${ }^{1}$ Geological Survey of Norway, N-7491 Trondheim, Norway. \\ E-mail corresponding author (Arne Bjørlykke): arne.bjorlykke@ngu.no
}

Keywords:

- Sandstone-hosted galena

- Basement faults

- Weathering

- Early Cambrian

- Seismic pumping

- Sweden

Received:

2. October 2020

Accepted:

28. March 20201

Published online:

16. August 2021
The Vassbo deposit is part of a group of sandstone-hosted lead deposits (Laisvall, Vassbo and Osen) in lower Cambrian sandstones (series 2) close to the Precambrian basement on the Baltoscandian Shield. The mineralised sandstone at Vassbo is part of a seaward-prograding nearshore environment with aeolian dunes and lagoons at the top. In the western part of the Baltoscandian Shield there was an uplift (Hawke Bay Event) and erosion before the middle Cambrian (Miolingian) transgression with deposition of the Alum Shale Formation. The observation of clasts with ore in the Hawke Bay conglomerate may put some limits on the timing of the ore formation. The ore deposits are related to basement faults with a magnetic low signature, which probably reflects deep weathering. Galena and sphalerite in these deposits occur as cement in the sandstone, commonly together with barite, fluorite, calcite, quartz or apatite. Tidal channels in the sandstone contain clasts of dark phosphorites with sphalerite and barite indicating an early ore formation in a nearshore environment. The first cement in the aeolian sandstone is apatite that is partly replaced by a later, second-generation cement containing apatite, sulphides and quartz. The clasts are well rounded and must have been lithified before the erosion. The surface of the clasts cuts the texture of both generations of cement and the clasts are commonly coated by pyrite, which implies that the main mineralisation took place before the Hawke Bay Event in early Cambrian time (Lower Cambrian) and the deposition of the conglomerate. The supply of phosphorous and iron adsorbed on aeolian sand gave an increased organic production, and sulphate reduction in the nearshore area. A redox front developed in the sandstone with barite and calcite forming in a sulphate zone and galena and sphalerite a sulphide zone. The sulphur isotope composition of sulphides indicates barite as a sulphur source. The $\mathrm{Pb}$ isotope composition of galena and barite show that lead and barium probably had a common source in the underlying basement. Orebodies in the Vassbo area show a clear spatial relationship with faults or shear-zones in the basement. The ore is epigenetic and seismic pumping in these faults/shear-zones was probably important in the ore-forming process. We propose that the hydrothermal ore solution was pumped into $\mathrm{H}_{2} \mathrm{~S}$-rich sandstones before the Hawke Bay Event. The temperature of the ore-forming solution is difficult to estimate because of later metamorphism.

Bjørlykke, A., Lepland, A. \& Skår, Ø. 2021: Origin of the mineralised Hawke Bay conglomerate and its importance in formation of the Vassbo lead-zinc deposit, Sweden. Norwegian Journal of Geology 101, 202109. https://dx.doi.org/10.17850/njg101-2-4.

(C) Copyright the authors.

This work is licensed under a Creative Commons Attribution 4.0 International License. 


\section{Introduction}

Many ore deposits occur in Phanerozoic carbonates and sandstones, and most common are copper, lead and zinc deposits. Redox changes and access to reduced sulphur are important factors for the ore-forming process. Lead-zinc deposits occur typically in marine sandstones and carbonates, whereas copper is commonly related to fluvial environments with sandstones and shales (Large et al., 2017; Bjørlykke \& Sangster, 1981). The relationship between fluid flow, tectonic activity on basement faults and ore formation has recently been published by Li et al. (2017).

Several sandstone-hosted lead-zinc deposits occur in Lower Cambrian sandstones both in autochthonous sediments and in the Lower Allochthon of the Caledonian orogeny (Fig. 1) close to the Ediacaran-Cambrian peneplain (Rickard et al., 1979; Bjørlykke \& Sangster, 1981; Romer, 1992;

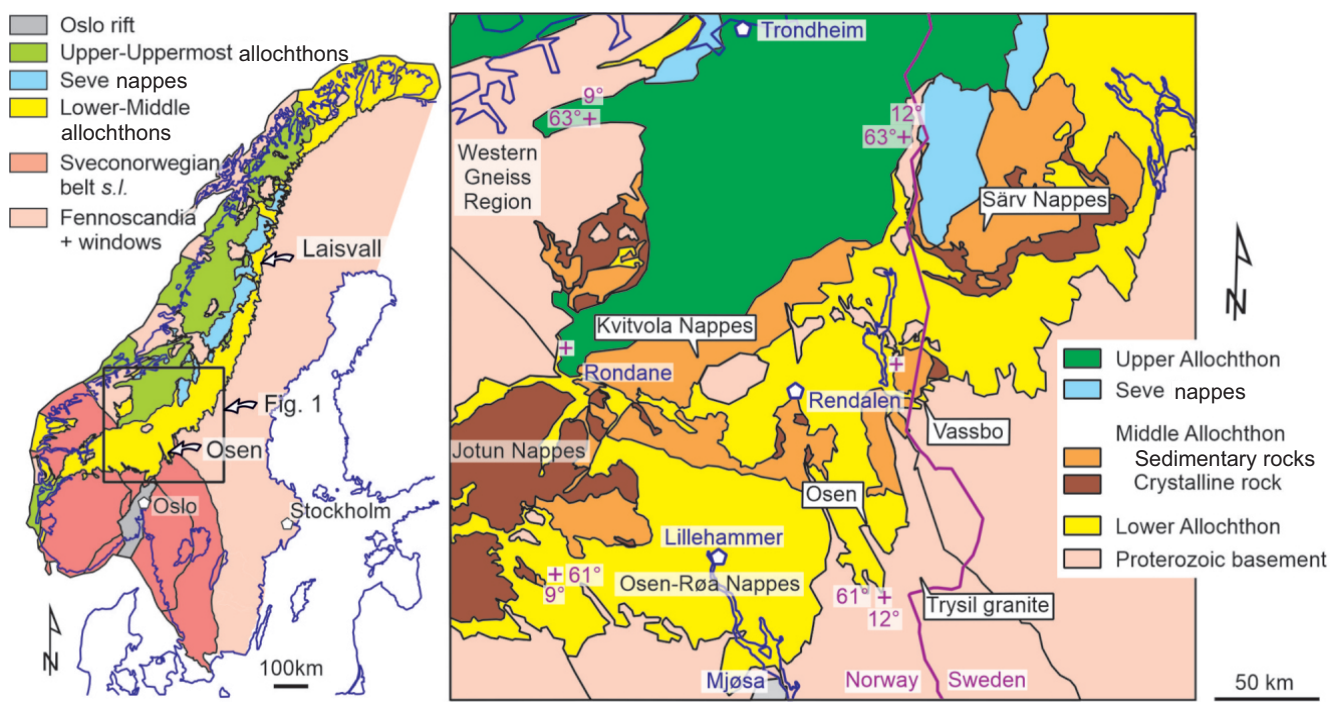

Figure 1. Tectonostratigraphic sketch map of Norway and Sweden with the locations of Osen, Vassbo and Laisvall. Modified from Bjørlykke et al. (2018).

Saintilan et al., 2015a, b). The Lower Cambrian sandstones represent nearshore deposits related to the marine transgression on the Baltoscandian Shield (Fig. 2). Galena and sphalerite form in association with barite, calcite and fluorite cement in the sandstone. Laisvall is the largest of such sandstone-hosted deposits in Scandinavia, with 80 million tons of ore grading 4\% Pb (Rickard et al., 1979). Two deposits of galena have been mined in the Vassbo area (Vassbo mine and Guttusjö mine). Vassbo mine is the largest deposit with 4.3 million tons averaging 4.6 wt.\% Pb and 0.3 wt.\% Zn, and the Guttusjö Mine with 2.7 million tons averaging $3.5 \mathrm{wt} . \% \mathrm{~Pb}$ (Zachrisson, 1980).

The genesis of these deposits has been explained by the migration of basinal brines during the Caledonian orogeny (Rickard et al., 1979), following the model of Mississippi Valley-type (MVT) deposits (Leach et al., 2010). Vertically moving brines related to basement structures have been proposed by Bjørlykke et al. (1991), Romer (1992) and Saintilan et al. (2015a). A Mid-Ordovician foreland bulging during the Caledonian orogeny has been suggested by Saintilan et al. (2015b).

In a study of noble gas and halogen in the ores from Laisvall, Vassbo and Osen by Kendrick et al. (2005), the authors concluded that the fluids must have had a long pre-mineralisation residence time in the Precambrian basement in the order of 100-200 myr. The authors also proposed seismic pumping as the driving force for the ore-forming solution and suggested a Silurian age for the mineralisation related to foreland bulging. 


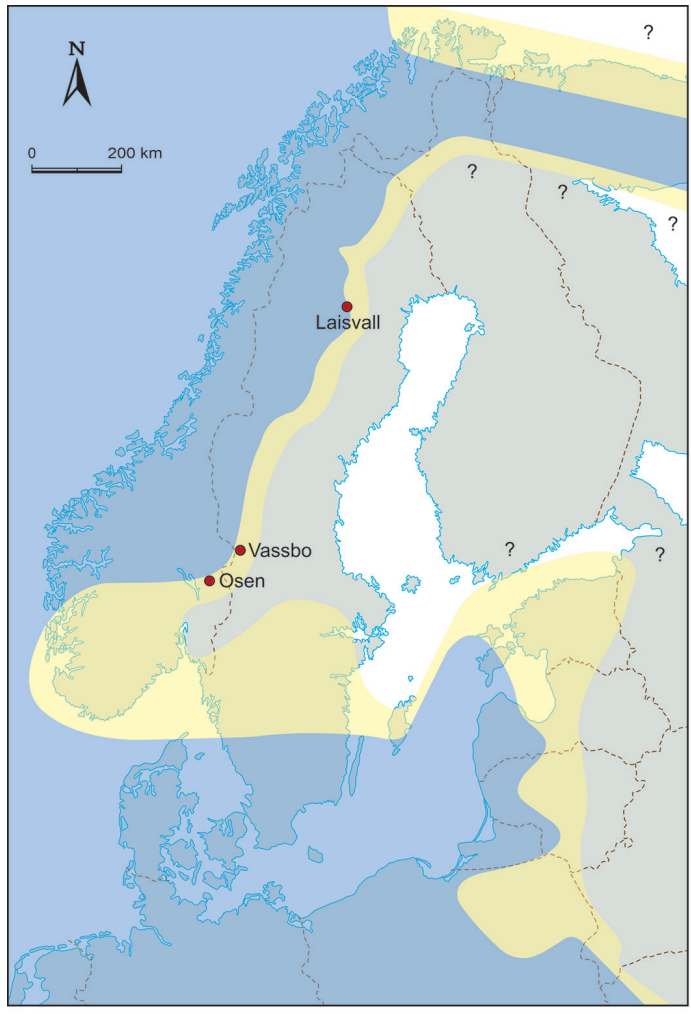

Figure 2. Paleogeographic map of Baltoscandia during the deposition of the Vassbo Formation. (Sequence LC2-3). Modified from Nielsen \& Schovsbo (2011).

Bjørlykke \& Sangster (1981) proposed that the formation of these deposits was related to chemical weathering of the underlying Precambrian basement. Bjørlykke \& Thorpe (1982) concluded that the isotope composition of the galena of the Osen deposit (Fig. 1) lies on an isochron with an age of 520 $\mathrm{Ma}$ and an initial ratio corresponding to the calculated composition of the Trysil granite 520 myr ago. Bjørlykke et al. (2018) used new Laser Ablation Multi-Collector Inductively Coupled Plasma Mass Spectrometry (LA-MC-ICP-MS) Pb isotope analyses of K-feldspar from the same samples of the Trysil granite used by Bjørlykke \& Thorpe (1982), and the new data gave an isochron with a model age of $540 \mathrm{Ma}$.

The conglomerate on the top of the ore at Vassbo is a result of the Hawke Bay Event on the Baltoscandian Shield (Nielsen \& Skovsbo, 2015) and the event is partly a result of eustatic regression and partly an uplift in the western part of Baltica. The Hawke Bay Event represents a hiatus of up to 6 myr. In this study we have examined the conglomerate at the top of the orebody and discuss the evidence for a mineralisation event before sedimentation of the Alum Shale Formation (Miolingian).

\section{Geology of the Vassbo area}

In the Vassbo area, Cambrian sandstones and shales were deposited on a weathered Precambrian peneplain. The autochthonous sedimentary sequence is cut by the thrust at the base of the Osen-Røa Nappe (Lower Allochthon) and most commonly the thrust lies within the Alum Shale Formation (Fig. 3). The lower Cambrian sediments were deposited in a seaward-prograding near-shore environment with aeolian dunes at the top (Wallin, 1982, 1989). Above the aeolian sandstone there is a conglomerate that was formed during the Hawke Bay Event. As noted above, the Hawke Bay Event (Fig. 4) represents a hiatus of close to 6 myr and the uplift was in the order of 50-100 metres (Nielsen \& Schovsbo, 2015). 

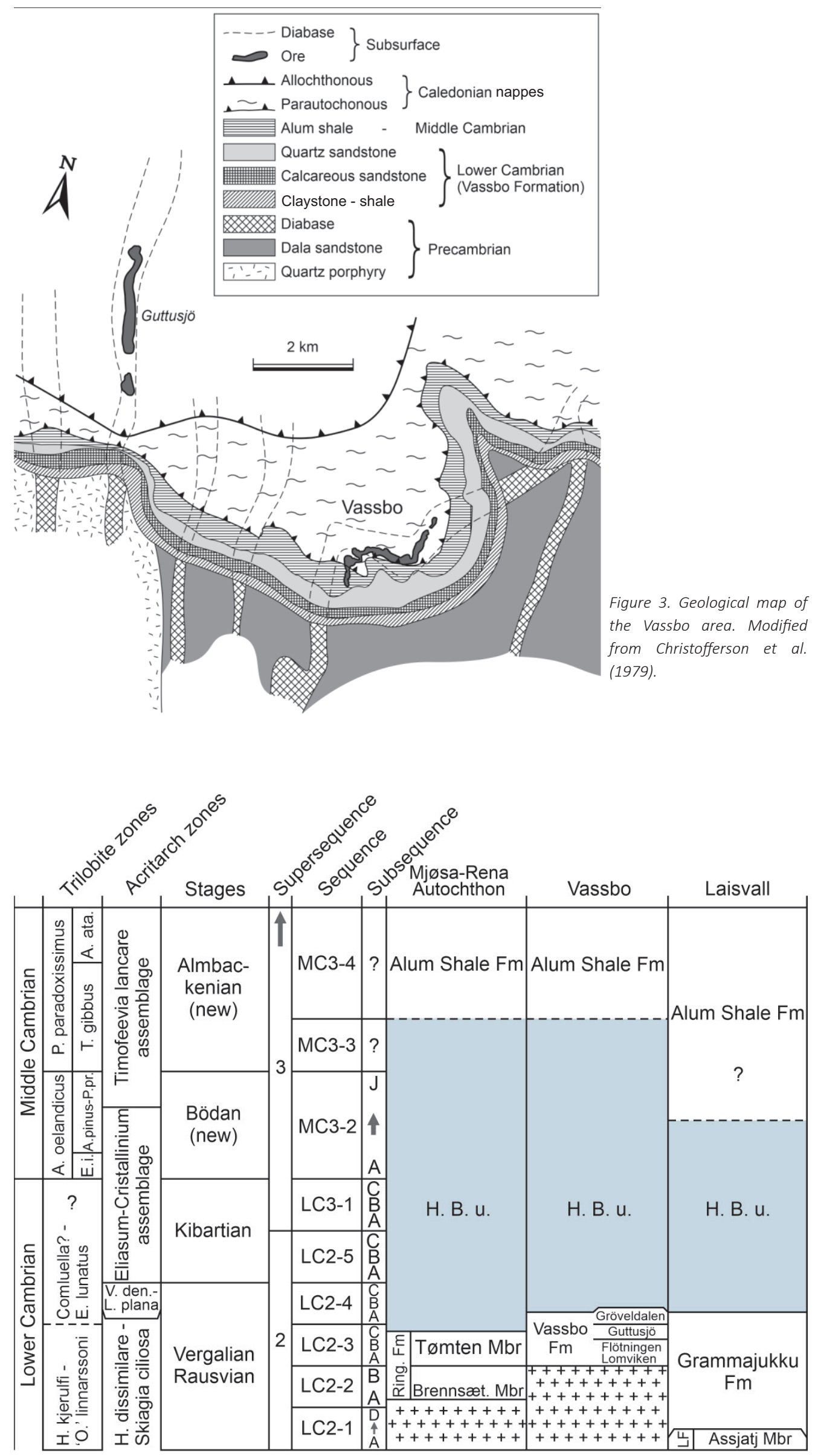

Figure 4. Correlation and lithostratigraphical division of the lower Middle Cambrian at Osen (Mjøsa-Rena allochthon), Vassbo and Laisvall. Modified from Nielsen \& Schovsbo (2015). H.B.u - Hawke Bay unconformity. 


\section{Precambrian basement}

The Precambrian basement in Vassbo (Fig. 3) consists of quartz porphyry rocks, sandstones and dolerite dykes. The quartz porphyry, dated at $1653 \pm 38 \mathrm{Ma}$ (Welin \& Lundquist, 1973), is part of a volcanic sequence that developed along the western margin of the Fennoscandian Shield. The sandstone is younger with an erosional contact above deformed quartz porphyry, and it consists of conglomerates with boulders mainly from the underlying porphyry and white to red sandstones with mainly quartz and 15\% feldspars (Tegengren, 1962). The dolerite dykes are dated at 980-950 Ma (Söderlund et al., 2005) and they intruded into Sveconorwegian tectonic structures (Tegengren, 1962). The main minerals in the dolerite dyke are olivine, pyroxene, plagioclase and biotite, and the dykes are strongly magnetic.

During the Neoproterozoic, continental rifting took place on the Fennoscandian Shield. The environmental conditions changed from a cold climate with glaciations to a warm climate with chemical weathering at the start of the Cambrian (Nystuen, 2008). In the early Cambrian the $\mathrm{CO}_{2}$-content in the atmosphere was probably 16 times the concentration of today (Schmitt, 1999) with the oxygen content being variable and with an increase from $5 \%$ to $20 \%$ (Large et al., 2017).

There is a clear connection between the faults in the basement, dolerite dykes and the trend of the Vassbo and Guttusjöen orebodies (Tegengren, 1962; Christofferson et al., 1979). The weathering of the dolerite dyke is more extensive than that of the porphyries and the sandstones (Tegengren, 1962; Christofferson et al., 1979; Saintillian et al., 2015a).

The Guttusjö deposit follows the Sveconorwegian NNW-SSE trend and occurs close to the fault-zone dividing the sandstone and the quartz porphyry in the Precambrian basement, mapped by Tegengren (1962). In the Guttusjö deposit, the basement depression above the dolerite dyke can be up to 10 metres (Christofferson et al., 1979) and the deepest parts are under the mine area. The Z-shape of the dolerite dyke under the Vassbo orebody (Fig. 3) is probably related to strike-slip faulting of the basement. Under the Vassbo mine, there is also a strongly weathered dolerite dyke, which forms a several metres deep depression in the peneplain (Christofferson et al., 1979).

Abundant magnetite in the dolerite dykes gives strong magnetic anomalies in the Vassbo area (Fig. 5, modified from Saintilan et al., 2015a). In the basement under the orebodies, there are, however, zones with very low magnetic susceptibility in the basement indicating a deep oxidation of magnetite in the dolerite, probably to a depth of more than 200 metres (Olesen et al., 2006; O. Olesen, pers. comm., 2019). Similar deep alteration can be found today in neotectonic structures, probably related to seismic pumping (Olesen et al., 2004). Muir-Wood \& King (1993) concluded that earthquake strain will release most fluids in normal faults. They also concluded that strike-slip faulting events typically also expel fluids in more restricted regions, but not in the same quantities.

The magnetic low areas on the aeromagnetic map may be explained by weathering of magnetite. Iron-rich silicates and iron-sulphides will also be oxidised and $\mathrm{Fe}^{3+}$ will first form ferrihydrite, $\mathrm{Fe}(\mathrm{OH})_{3}$. Ferrihydrite has a high capacity to adsorb metals, phosphorus and silica (Appello \& Postma, 2005). The formation of ferrihydrite will result in an increase in volume, connected porosity and hydraulic conductivity. The formation of ferrihydrite by alteration of biotite is an important result of the weathering process (Goodfellow et al., 2016). A mineralogical change from the more unstable ferrihydrite to goethite or hematite will reduce the volume of iron minerals and increase the porosity in the alteration zone. 


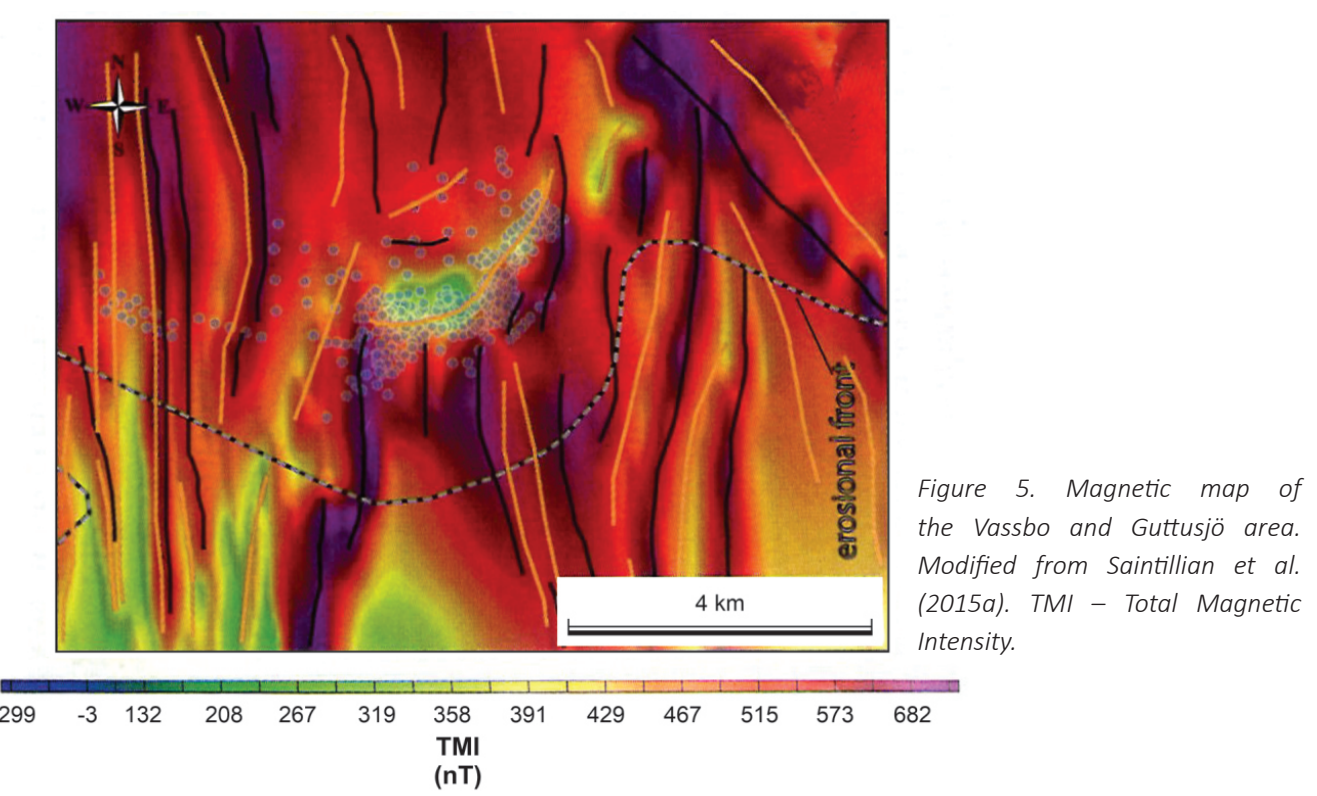

$\because \bullet$ Exploration boreholes delineating the Vassbo mineralisation

Interpretation of airborne magnetic data

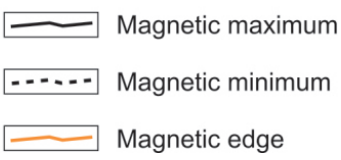

\section{Vassbo Formation}

The marine transgression and sedimentation of the Vassbo Formation started in the middle period (LC2-3 (4?)) of the early Cambrian (Fig. 4, Nielsen \& Schovsbo, 2015). The thickness of the Vassbo Formation varies from 20 to 30 metres, and Wallin (1982) interpreted the depositional environment in terms of a simple seaward-prograding coastal model, where the Flötningen Member is the offshore facies, the Guttusjöen is the shore facies and the Gröveldalen Member contains the foreshore, backshore and aeolian dunes, facies (Fig. 6).

The hiatus under the Alum Shale Formation (Figs. 4 \& 6) represents the Hawke Bay Event and the Kibartian Stage (LC2-5) is missing.

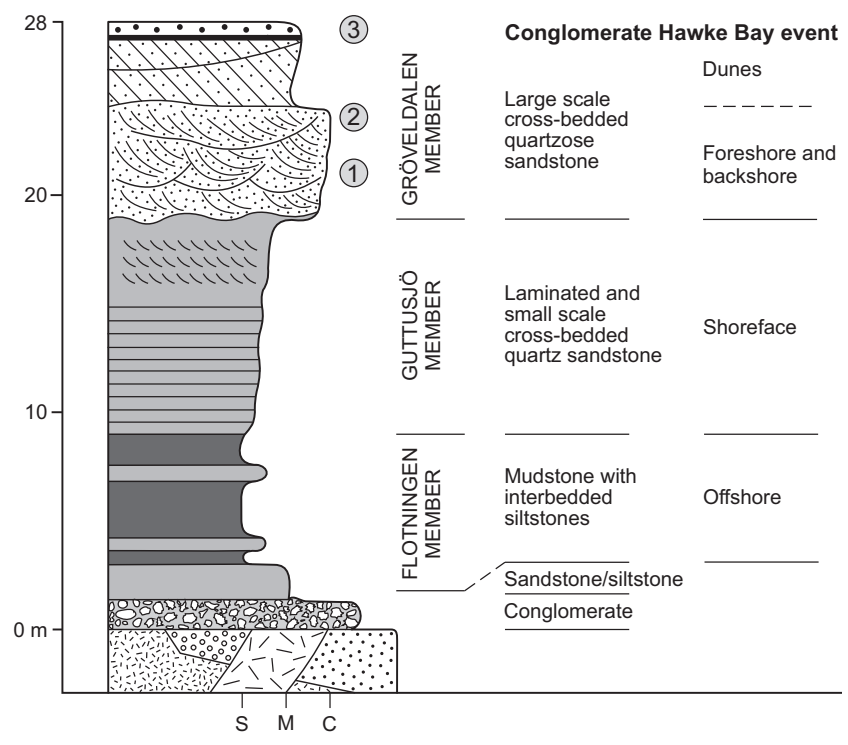

Figure 6. Lithostratigraphic summary of the autochthonous Cambrian sequence at Vassbo (modified after Wallin, 1982). Sampling sites are indicated. Site 1 is the transport tunnel near the shaft. Sites 2 and 3 are in the open pit. 


\section{Lomviken and Flötningen members}

The basal beds, the Lomviken Member, consist of conglomerate, mixtite and sandstone. They are usually 10-20 cm thick, and the thickness increases rapidly toward the northwest in the Guttusjö area. The Lomviken Member is succeeded by the Flötningen Member, which consists mainly of interbedded sandstone and siltstone in the basal part, and mudstone with intercalated siltstone beds in the upper part. The total thickness is about 7 metres. The feldspar content is generally below $10 \%$, with microcline as the dominant variety. Small-scale cross beds, ripplemarks, flaser bedding, load casts, and ball-and-pillow structures have been described by Wallin (1982).

Guttusjö Member

The Flötningen Member is overlain by the Guttusjö Member, which comprises up to $18 \mathrm{~m}$ of sandstone. The dark grey sandstone, which is interbedded with siltstone and mudstone in the basal and middle parts, is massive or laminated and very fine-grained. Some phyllosilicates occur in the matrix and the cement consists mainly of calcite and quartz with minor pyrite, galena and sphalerite. The $\mathrm{O}$ and $\mathrm{C}$ isotope compositions of the calcite indicate that meteoric water played an important part in the formation process (Wallin, 1982). A marked erosional disconformity occurs between the Guttusjöen Member and the overlying Gröveldalen Member, which is the uppermost member in the Vassbo Formation (Wallin, 1982).

\section{Gröveldalen Member}

The Gröveldalen Member, hosting the ore deposits both in Vassbo and in Guttusjöen, averages $8 \mathrm{~m}$ in thickness. The lower part of the Gröveldalen Member (facies a, Wallin, 1982) consists of mediumto fine-grained quartzite, commonly cross-bedded and in places interbedded with coarse sandstones. The sandstone of the upper part, (facies b, Wallin, 1982), is interpreted to represent aeolian dunes. The upper sandstone is missing in the Guttusjö area.
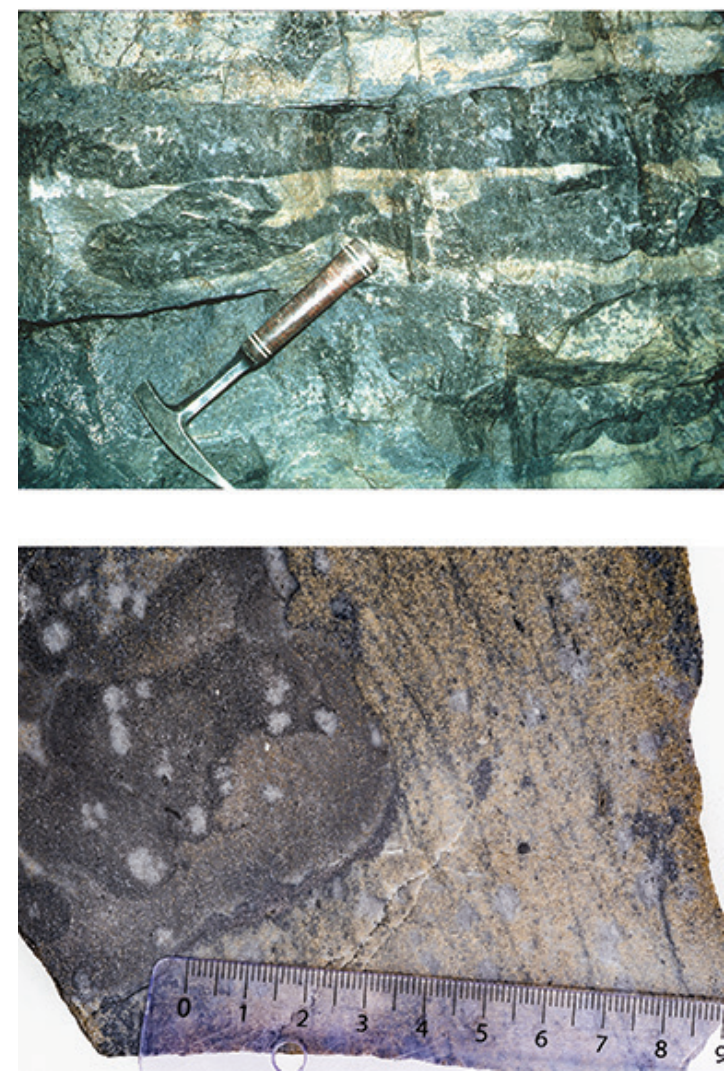

Figure 7. (A) Reduction-oxidation fronts in the lower part of the Gröveldalen Member The pale yellowish colour shows sphalerite and galena, and the darker areas consist of barite, calcite and some galena cement. Photo is from sampling site 1 (Fig. 6). (B) A closeup of the lenticular bedding with sphalerite cut by poikiloblasts with barite and calcite (light grey) - the sample is approximately 15 by $15 \mathrm{~cm}$. NGU sample ID 
The lower part of the Gröveldalen Member is characterised by trough cross-bedding and units with planar cross-bedding together with ripples and convolute bedding (Wallin, 1982). Quartz, calcite, galena, sphalerite, pyrite and barite (minor fluorite) occur as cement. Galena is the dominant cement with $3-5 \%$ in the orebody. The sphalerite content is approximately $0.5 \%$ and calcite 1-2\% (Wallin, 1982). The cement may follow sedimentary structures like cross-bedding or form round poikilitic textures overprinting primary structures (Fig. 7). In some places there are alternating galena and barite laminae following the cross-beds (Christofferson et al., 1979).

There are tidal channels that are characterised by barite-cemented sandstone and clasts of dark apatite-cemented shale/mudstone with illite and some potassium feldspar. Some of the clasts are cut by veins of barite (Fig. 8A) showing an early barite precipitation. The dark clasts have disseminations of sphalerite with a minor amount of pyrite, and they are commonly coated by galena (Fig. 8B). The dark clasts probably represent deposits formed in lagoons in the coastal environment.
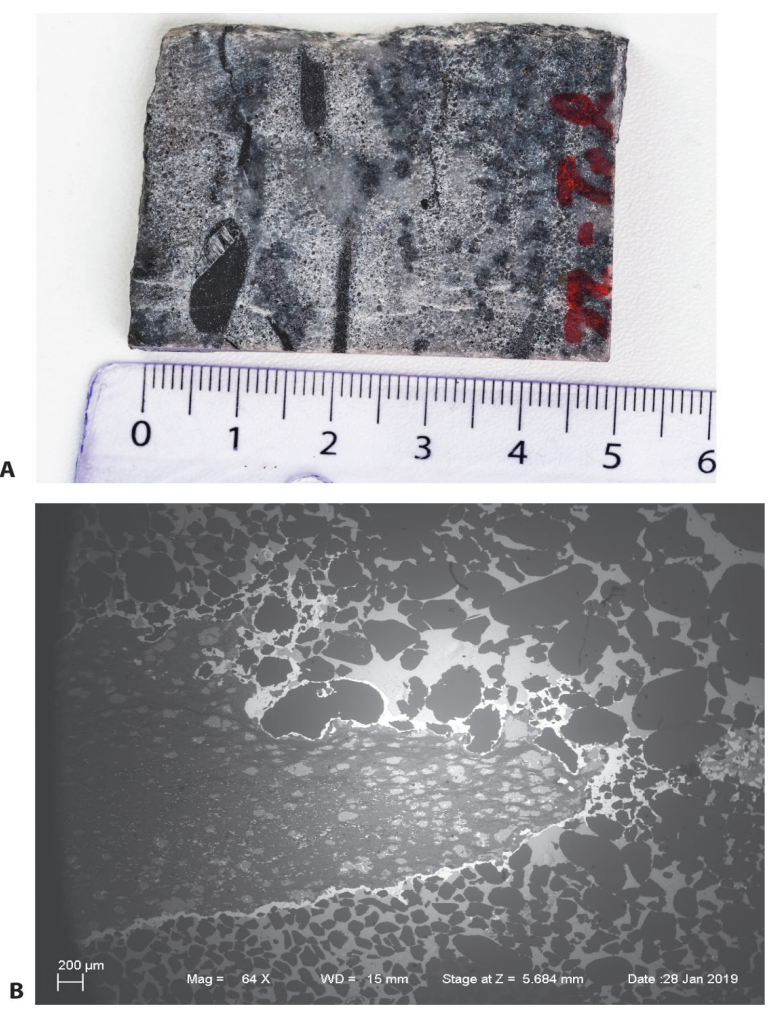

Figure 8. (A) Tidal channel with sandstone and dark shale clasts with a barite vein and dark clasts with disseminated sphalerite and minor galena and pyrite. The sample is from the open pit, site 2 (Fig. 6). NGU sample ID 132198. (B) A SEM image of the same clast (Fig. 8A), which is approximately $3 \mathrm{~mm}$ thick and coated by galena.

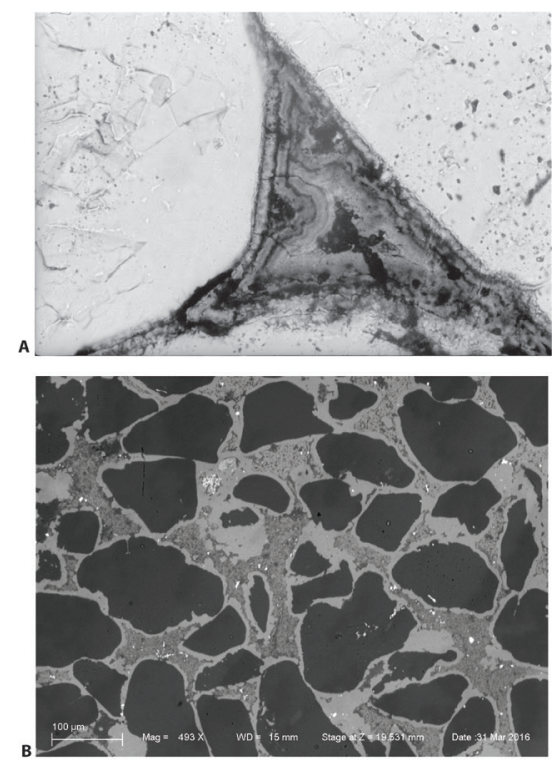

Figure 9. (A) Clasts in the Hawke Bay conglomerate in the open pit, sampling site 3 (Fig. 6). First generation of apatite cement in the aeolian sandstone with some organic material coating the sand grains. The image is approximately $1 \mathrm{~mm}$ wide. NGU ID 136519. (B) A later phase with quartz, sulphides and apatite is cross-cutting and corroding the organic apatite. NGU sample ID 136519. 


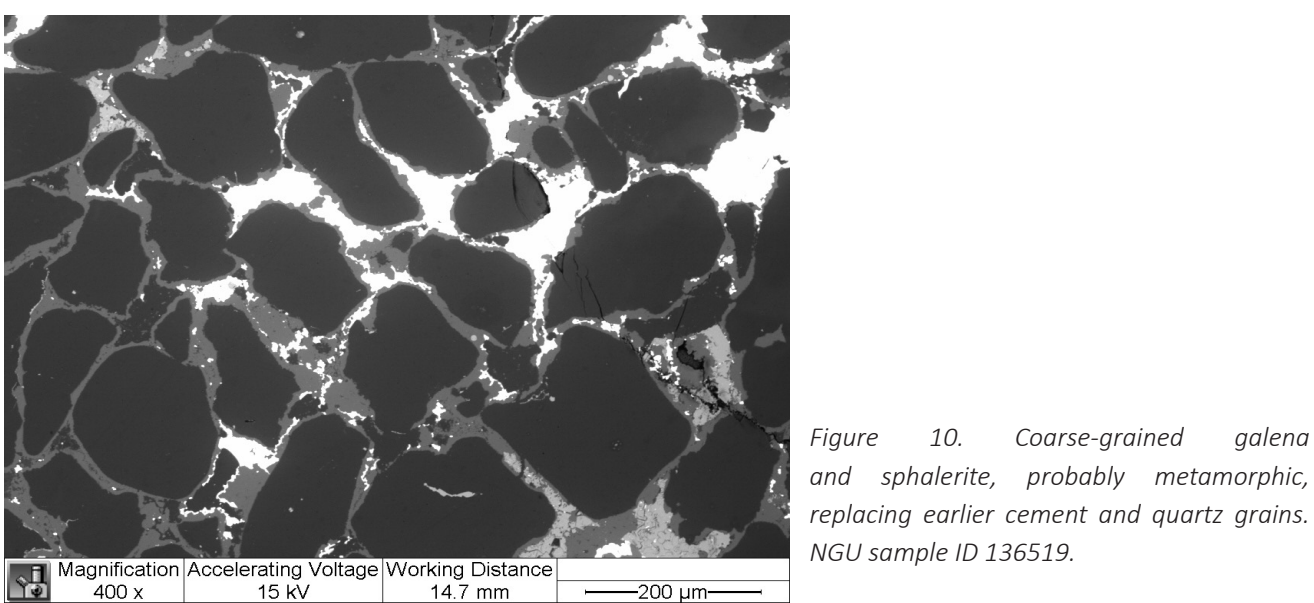

The upper part of the Gröveldalen Member consists of a fine-grained black sandstone and with highangle planar cross-bedding indicating an aeolian origin (Wallin, 1982). There are two generations of cement in the dark sandstone. The first generation occurs as a laminated darker coating (carbon-rich) and lighter-coloured apatite on quartz grains (Fig. 9A). Formation of such coating may be microbially mediated. Locally, one can see etching of the quartz grains. Elsewhere there is also an early quartz overgrowth on quartz grains. A second generation of apatite cement fills the porosity between the apatite-coated sand grains, and in places occurs as replacement of the first generation of apatite (Fig. 9B). Apatite of the second generation occurs together with quartz and fine-grained disseminated pyrite, galena and sphalerite. This second generation is probably of the same generation as the main ore-forming event in the lower part of the Gröveldalen Member. Coarser grains of sulphides, probably metamorphic, commonly cut the border between the two apatite generations, replacing primary quartz grains (Fig. 10).

\section{Conglomerate of the Hawke Bay Event}

The hiatus related to the of Hawke Bay Event is estimated by Nielsen \& Schovsbo (2015) to have lasted up to $6 \mathrm{myr}$, and the erosion of lower Cambrian sediments is estimated to be between 5 and 10 metres. The boundary to the overlying middle Cambrian (Miolingian) Alum Shale, is very sharp and the Alum Shale is draped over the clasts in the conglomerate. The conglomerate contains clasts of aeolian sandstones, clasts of the conglomerate and phosphorites. The conglomerate can be correlated with the Ölandicus conglomerate (Skjeseth, 1963) from the Mjøsa district in Norway, where Skjeseth has described phosphorites, an angular erosional disconformity and a weak dissemination of galena.

The conglomerate is developed throughout the Vassbo area, and it was best exposed in the open pit at the Vassbo mine, above a cross-bedded unit of the Gröveldalen Member. There is a clear angular discordance below the conglomerate, and it was deposited on the upper aeolian sandstone to the east at Vassbo mine, and directly on lower foreshore and backshore sandstone in the west, at Guttusjöen (Wallin, 1982).

The conglomerate is 10 to $20 \mathrm{~cm}$ thick (Fig. 11) and contains dark grey to black cobbles and pebbles, commonly ellipsoidal in shape, with the two longest axes parallel to the bedding. The maximum length of the longest axes is approximately 10-15 cm. Most of the clasts are dark, fine-grained, probably aeolian sandstone from the upper part of the Gröveldalen Member (Wallin, 1989). Fig. 11A shows a sulphide-depleted zone close to the surface of the largest cobbles, that may be related to the oxidising conditions during the Hawke Bay Event. Occurrence of conglomerate clasts indicates more than one cycle of erosion and deposition (Fig. 11B). Most of the sandstone clasts are well rounded, indicating lithification before the erosion. 
A
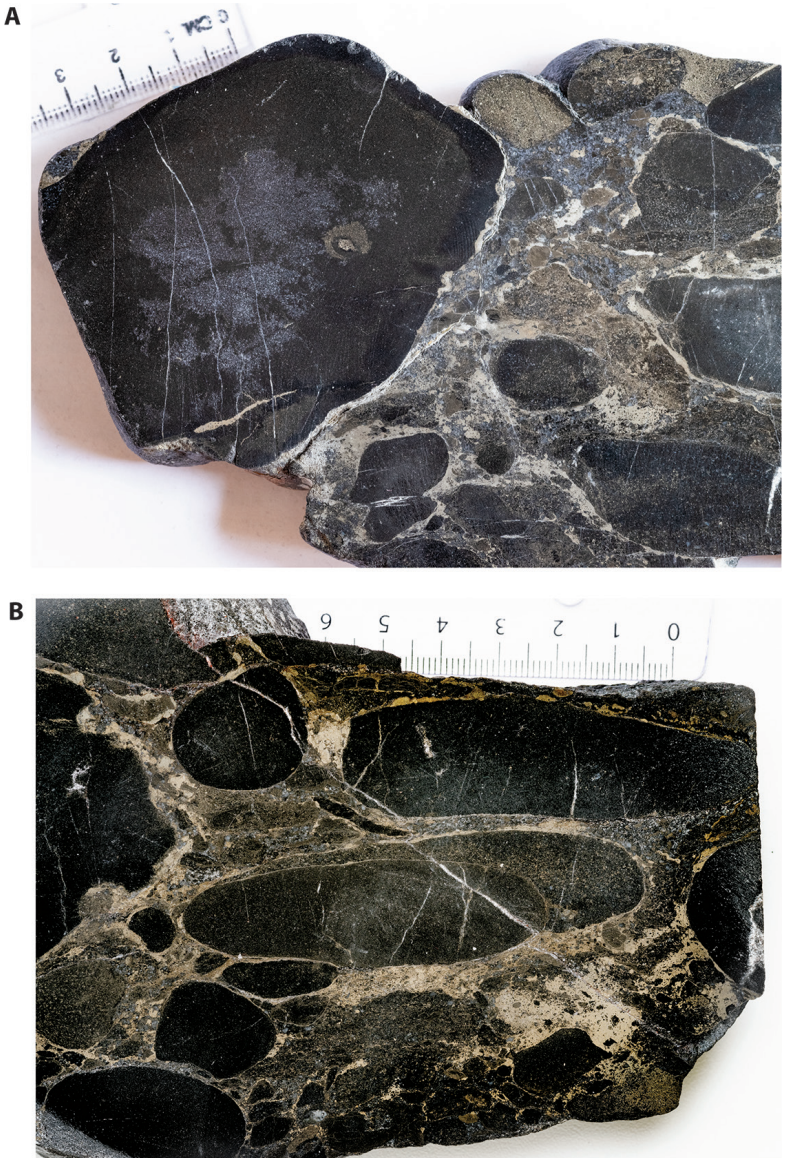

Figure 11. (A) A cross-section of the conglomerate showing rounded clasts with galena and minor pyrite and the matrix with dominantly pyrite. The diameter of the rounded clast with galena cement is approximately $5 \mathrm{~cm}$ (Sampling site 3). (B) Conglomerate with clasts showing more than one cycle of erosion and deposition (Sampling site 3).
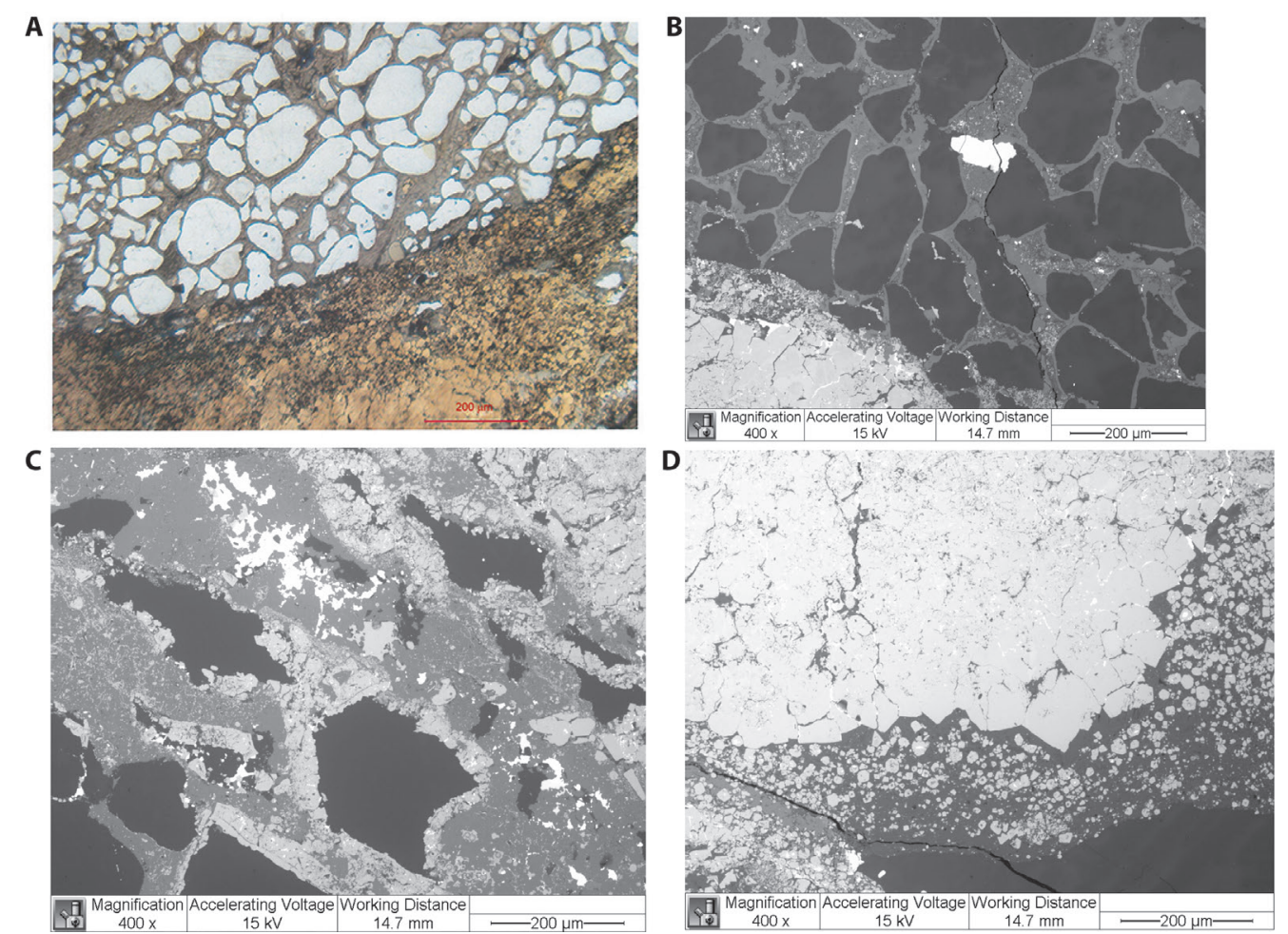

Fig 12. Sample ID 132200. (A) The surface of clast of aeolian sandstone coated by pyrite. The sulfide coating is cutting both the laminated apatite and the quartz - sulfide cement. (B) A close up with a SEM picture of the same surface. Observe also the fine-grained primary sulfides together with apatite, quarts, and calcite, and later metamorphic galena. (C) Chert fragments with pyrite coating and phosphorite and sulfides in the matrix. (D) Growth of pyrite on a clast of aeolian sandstone. Framboidal pyrite in the matrix. 
Pebble-size clasts of aeolian sandstone are commonly coated by pyrite (Fig. 12A). The boundary between the pebbles and the pyrite coating is sharp and the pyrite cross-cuts both the first and the second generations of apatite cement in the pebbles (Fig. 12B), which shows that the ore-forming process took place before the precipitation of the pyrite coating of the pebbles in the conglomerate.

Angular clasts/grains of chert and phosphorite occur in the matrix of the conglomerate, often coated with pyrite (Fig. 12C). The cement is rich in quartz and pyrite, which occur together with apatite, galena and sphalerite. In addition to the sandstone clasts there are angular to subangular fragments of chert, shales with phosphorites and organic material. Most clasts have a rim of pyrite on the surface with minor dissemination of galena and sphalerite. The sulphide coating of the clasts may be related to sulphide alteration of an earlier iron-hydroxide coating during the Hawke Bay Event.

Fine-grained framboidal pyrite (Fig. 12D) occurs between the clasts and in phosphorites, which indicates an open access to seawater sulphur during the start of the Middle Cambrian transgression (Alum Shale Formation).

\section{Diagenesis and metamorphism}

The Alum Shale Formation was deposited directly on the conglomerate related to the Hawke Bay Event and at that time most of the Baltoscandian Shield was covered by the sea. The degradation of the fossil remains indicates a temperature of approximately 220 degrees Celcius (M. Smelror, pers. Comm.). The maximum burial temperature was $250-300^{\circ} \mathrm{C}$ based on reflectivity of vitrinite and clay mineralogy (Snäll, 1988), mainly from sedimentary rocks in the Lower Allochthon. Late diagenetic to metamorphic muscovite crystals can be seen cross-cutting the sulphide minerals at Vassbo (Fig. 13).

The Middle Allochthon with the Kvitvola Nappe was thrusted onto the Baltoscandian margin of the Fennoscandian Shield at around $420 \mathrm{Ma}$ and resulted in the formation of Silurian foreland basins. The Lower Allochthon was thrusted later during the early Devonian (Bjørlykke \& Olesen, 2018; Ladenberger et al., 2014; Fossen et al., 2013). The thrusting of the Lower Allochthon resulted in an increased illite crystallinity in the autochthonous sedimentary rocks closer to the thrust plane (Rickard et al., 1979). There is no evidence of foreland bulging so far east as Vassbo during the Ordovician as proposed by Santilian et al. (2016).

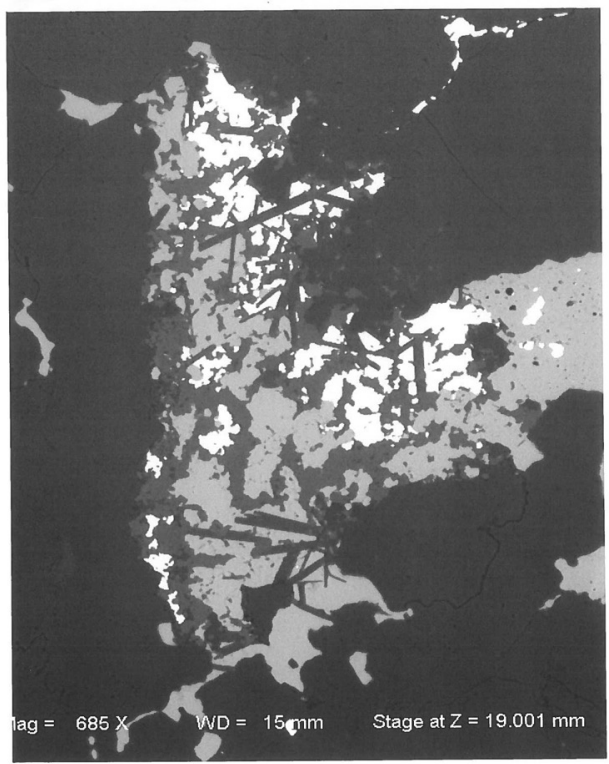

Figure 13. Metamorphic muscovite cross-cutting the sulphide minerals. Sample ID 132200 


\section{Lead isotopes}

\section{Analytical method for $\mathrm{Pb}$ isotopes}

Samples of the Middle Cambrian conglomerate (Hawke Bay Event) and conglomerate within the lower part of the Gröveldalen Member were selected for $\mathrm{Pb}$ isotope analyses. The separation process started with drilling a core approximately $6 \mathrm{~mm}$ in diameter. The sample was crushed and samples with sulphide and barite were hand-picked. It was difficult, in some sulphidic matrix samples, to separate the sulphides and a mixed sulphide sample was analysed. Both barite cement and fragments of barite from samples deposited in tidal channels were selected.

The various minerals were crushed and milled in different mills to avoid contamination because of the large difference in $\mathrm{Pb}$ concentrations. Pyrite and barite were milled in hand agate mill, galena in a hand steel mill. The samples were weighed directly in $50 \mathrm{ml}$ transparent polypropylene tubes with caps, $7 \mathrm{~N} \mathrm{HNO}_{3}$ was added and the samples were heated for 30 minutes at $200 \mathrm{kPa}$ and $120^{\circ} \mathrm{C}$ in an autoclave, following Norwegian Standard (NS 4770). Samples of barite were only partly dissolved and were therefore filtered through filter paper; the other samples were, to various degrees, dissolved, but filter papers were not used. Blank samples followed the same procedure. After extraction/digestion, the samples were diluted and analysed by ICP-OES to determine the concentration of $\mathrm{Pb}$ before final dilution to $2 \% \mathrm{HNO}_{3}$ $(\mathrm{v} / \mathrm{v})$ and analysis on ICP-MS. The instrumentation at NGU is a Thermo Element XR single collector highresolution ICP-MS, Cetac ASX-520 autosampler and Cetac DSA (Discrete Sampling Accessory) sample loop system. The teflon spray chamber and microflow nebulizer used are from Elemental Scientific. The following isotopes were measured: Masses ${ }^{202} \mathrm{Hg},{ }^{204}(\mathrm{Hg}+\mathrm{Pb}),{ }^{206} \mathrm{~Pb},{ }^{207} \mathrm{~Pb},{ }^{208} \mathrm{~Pb}$. The operation conditions of the ICP-MS and the detailed data acquisition parameters for the method are listed in Table 1. The interference on ${ }^{204} \mathrm{~Pb}$ from $\mathrm{Hg}$ in $\mathrm{Ar}$ gas was corrected by monitoring ${ }^{202} \mathrm{Hg}$ and assuming a ${ }^{204} \mathrm{Hg} /{ }^{202} \mathrm{Hg}$ ratio of 0.2293 . The measured isotope ratios were corrected for element- and mass-bias effect by using the Spectrapure Standards SI-100 Pb standard (Lot no: 103), which is traceable to NIST SRM 981 and with identical isotopic ratios. All data reduction was performed in MS Excel spreadsheets.

Table 1. Operation conditions and parameters for $\mathrm{Pb}$ isotope measurements on ICP-MS-

\begin{tabular}{ll}
\hline Forward power & $1250 \mathrm{~W}$ \\
Cool gas flow & $16.0 \mathrm{~L} / \mathrm{min}$ \\
Auxiliary gas flow & $0.90 \mathrm{~L} / \mathrm{min}$ \\
Sample gas flow & $1.09 \mathrm{~L} / \mathrm{min}$ \\
Cones & Ni standard cones \\
Scan type & Fixed magnet with electric scan over the mass ranges \\
Mass resolution & 300 (m/DM) \\
Detection mode & Analogue \\
Mass scanning window & $10 \%$ \\
Dwell time per isotope & $80 \mathrm{~ms}$ \\
Scan duration per mass & $400 \mathrm{~ms}$ \\
Numbers of scans & 100 \\
\hline
\end{tabular}


Natural sulphide minerals from two Norwegian mines were used to determine the analytical precision and accuracy, galena (NGU-90821) from the Mutta-Grua mine and pyrite (NGU-90822) from the Løkken mine. The sulphides were analysed over three days, 20 analyses of the pyrite and 18 analyses of the galena (Table 2). Although, these are not the same samples as those from which Bjørlykke et al. (1990, 1993) published data, they show conformity with those $\mathrm{Pb}$ isotope ratios. The differences between the $\mathrm{Pb}$ isotope ratios in the pyrites from $\mathrm{L} \varnothing \mathrm{kken}$ are $0.1 \%$ or less, and for the galenas from Mutta-Grua the differences are $0.04 \%$ or less (Table 2). This indicates that the $\mathrm{Pb}$ isotope compositions from those localities must be homogeneous on a large scale. RSD (\%) for the same analyses of the pyrite and galena during the three days are from $0.17 \%$ to $0.22 \%$, and from those data the estimated ( 2 standard deviation) analytical precisions are $0.9 \%$ for the isotope ratios ${ }^{206} \mathrm{~Pb} /{ }^{204} \mathrm{~Pb},{ }^{207} \mathrm{~Pb} /{ }^{204} \mathrm{~Pb}$ and ${ }^{208} \mathrm{~Pb} /{ }^{204} \mathrm{~Pb}$.

Table 2. Summary of analytical precision and accuracy of Pb isotope measurements.

\begin{tabular}{lccccc}
\hline & ${ }^{206} \mathrm{~Pb} /{ }^{204} \mathrm{~Pb}$ & ${ }^{207} \mathrm{~Pb} /{ }^{204} \mathrm{~Pb}$ & ${ }^{208} \mathrm{~Pb} /{ }^{204} \mathrm{~Pb}$ & ${ }^{207} \mathrm{~Pb} /{ }^{206} \mathrm{~Pb}$ & ${ }^{208} \mathrm{~Pb} /{ }^{206} \mathrm{~Pb}$ \\
\hline Pyrite Løkken ${ }^{\text {a) }}$ & 17.699 & 15.465 & 37.161 & 0.87378 & 2.0997 \\
Average of 20 analysis over 3 days & 17.680 & 15.463 & 37.187 & 0.87457 & 2.1033 \\
1 SE & 0.031 & 0.034 & 0.086 & 0.00164 & 0.0040 \\
RSD (\%) & 0.18 & 0.22 & 0.23 & 0.19 & 0.19 \\
Accuracy (\%) & 0.10 & 0.01 & -0.07 & -0.09 & -0.17 \\
& & & & & \\
Galena Mutta-Gruab) & 18.248 & 15.552 & 38.308 & 0.85224 & 2.0992 \\
Average of 18 analysis over 3 days & 18.255 & 15.556 & 38.294 & 0.85218 & 2.0978 \\
1 SE & 0.030 & 0.027 & 0.078 & 0.00110 & 0.0035 \\
RSD (\%) & 0.17 & 0.17 & 0.20 & 0.13 & 0.17 \\
Accuracy (\%) & -0.04 & -0.03 & 0.03 & 0.01 & 0.07 \\
Estimated analytical precision (\%) & 0.90 & 0.90 & 0.90 & 0.60 & 0.60 \\
\hline
\end{tabular}

a) Data from Bjørlykke et al. (1993).

b) Data from Bjørlykke et al. (1990). Samples analysed in this study is pyrite NGU-90822 and galena NGU-90821 from the same localities.

\section{Results}

The $\mathrm{Pb}$ isotope data are listed in Table 3 and presented in Fig. 14B. All the data plot within the analytical uncertainty of the method, indicating a common source of lead in the sulphide and barite samples (Fig. 14B).

There is no significant difference in the $\mathrm{Pb}$ isotope composition between sulphides in the rounded clasts in the conglomerate and the sulphides in the matrix. The conglomerate was formed above the orebody and the clasts with sulphides are interpreted to be erosional/weathering products formed during the Hawke Bay Event.

The $\mathrm{Pb}$ isotope data are compared with earlier analysed samples of the Vassbo orebody (Bjørlykke \& Thorpe, 1982). The mineralisation in Osen is probably of the same age as that at Vassbo and the basement source has a similar age. The Vassbo samples plot close to the $540 \mathrm{Ma}$ Osen isochron (Fig. 14A, Bjørlykke et al., 2018). The data from Vassbo are slightly more radiogenic than those found in the Osen samples, indicating a higher $\mathrm{U} / \mathrm{Pb}$ ratio in the source rock. 


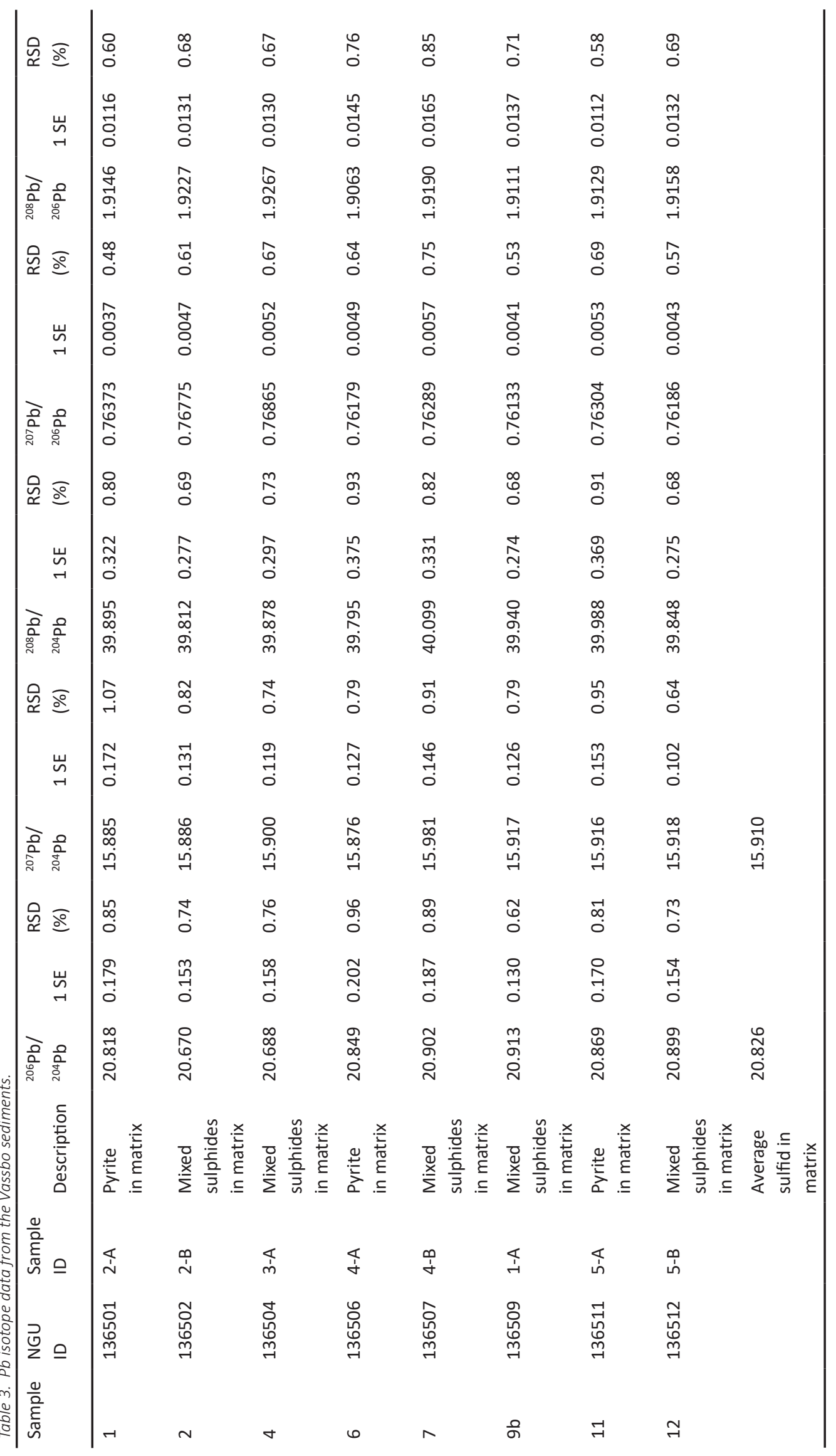




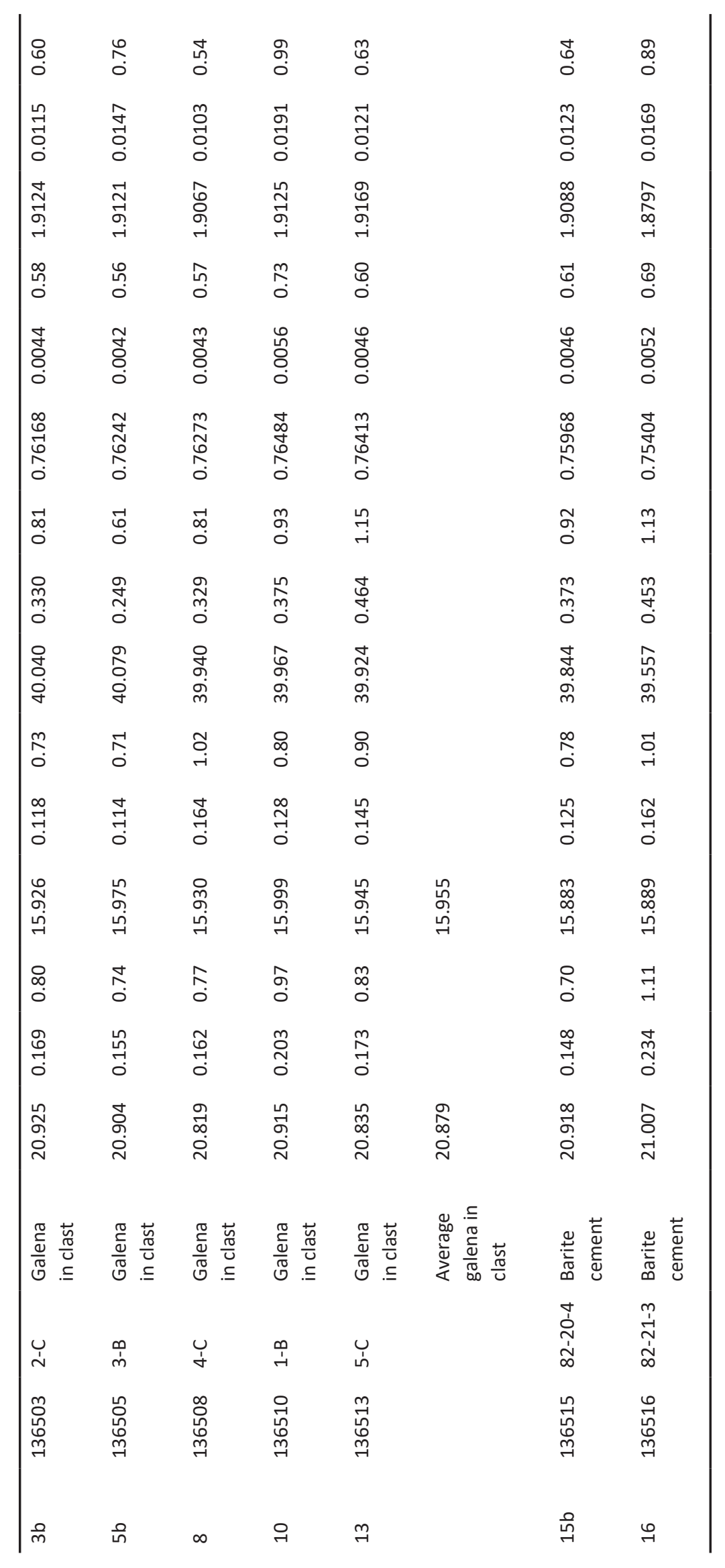



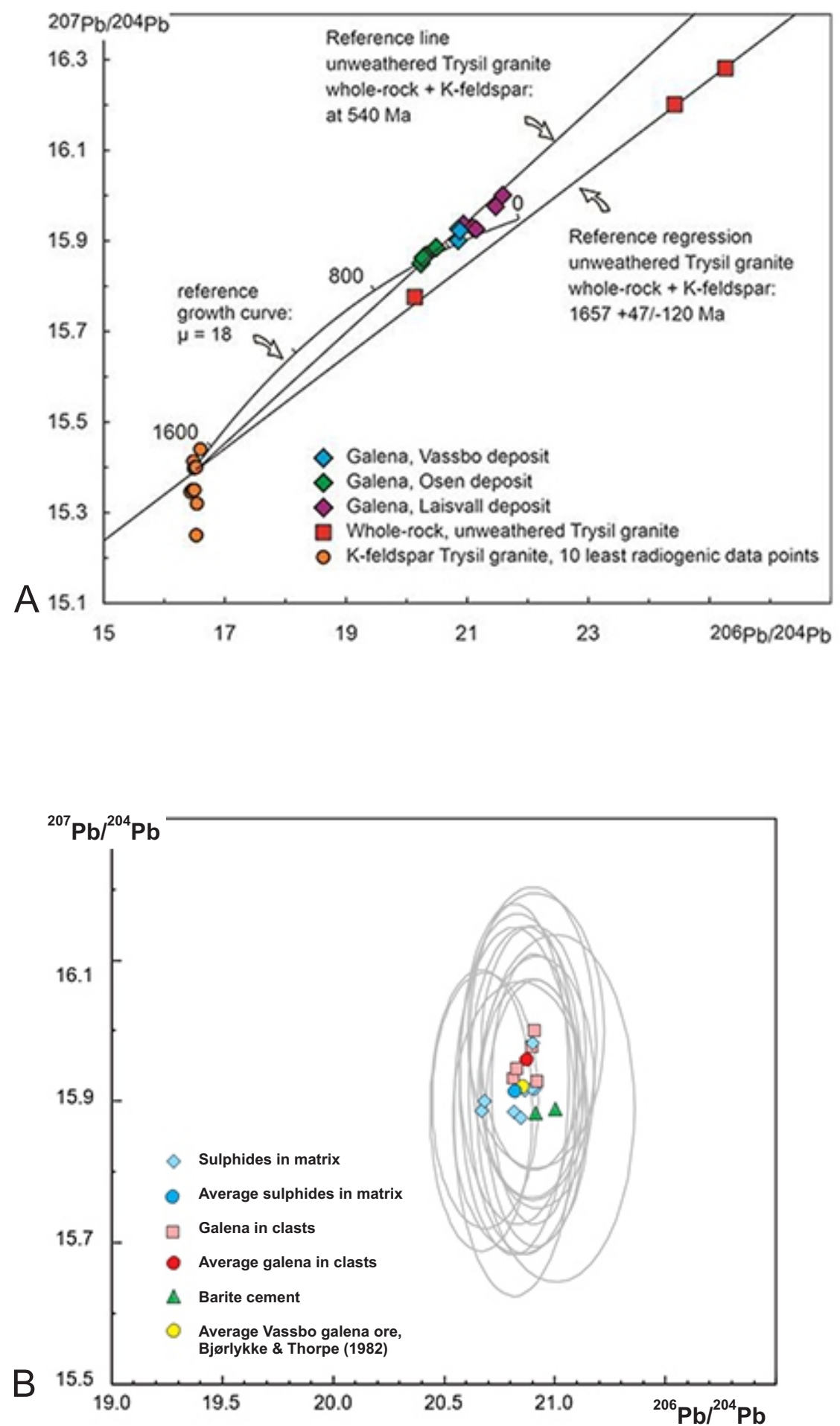

Figure 14. (A) Lead isotope data from the Vassbo and Osen deposits. Modified from Bjørlykke et al. (2018). (B) Lead isotope composition of sulphides and barite from Vassbo, this study. 


\section{Sulphur isotope composition}

\section{Analytical method for sulphur isotopes}

Barite $\left(\mathrm{BaSO}_{4}\right)$, galena $(\mathrm{PbS})$ and pyrite $\left(\mathrm{FeS}_{2}\right)$ were analysed for multiple sulphur isotopes at McGill University, Canada. Samples containing pyrite and galena were first crushed and $\approx 0.2-15 \mathrm{~g}$ of sample was loaded into a reaction vessel. Vessels were first flushed with $\mathrm{N}_{2(\mathrm{~g})}$ followed by the addition of 15 $\mathrm{mL}$ of $6 \mathrm{M} \mathrm{HCl}$ and then $15 \mathrm{~mL}$ of $1 \mathrm{M}$ chromic chloride $\left(\mathrm{CrCl}_{3}\right.$ ), $0.5 \mathrm{M} \mathrm{HCl}$ solution (Canfield et al., 1986). Reaction vessels were then heated and hydrogen sulphide $\left(\mathrm{H}_{2} \mathrm{~S}\right)_{(\mathrm{g})}$ was released from samples. For samples of barite, instead of a chromic chloride $\mathrm{H} \neg \mathrm{Cl}$ solution, $\approx 5-15 \mathrm{mg}$ of barite was reacted with Thode solution $\left(\mathrm{HI}, \mathrm{HCl}, \mathrm{H}_{3} \mathrm{PO}_{2}\right.$ ) at $\approx 100^{\circ} \mathrm{C} . \mathrm{H}_{2} \mathrm{~S}_{(\mathrm{g})}$ from both sulphide and sulphate samples was then carried through a $\mathrm{N}_{2(\mathrm{~g})}$ stream and bubbled first through a water trap, and then through a zinc acetate solution to convert $\mathrm{H}_{2} \mathrm{~S}_{(\mathrm{g})}$ to $\mathrm{ZnS}_{(\mathrm{s})}$. Vials with $\mathrm{ZnS}_{(\mathrm{s})}$ were then reacted with $0.1 \mathrm{M}$ silver nitrate to form $\mathrm{Ag}_{2} \mathrm{~S}_{(\mathrm{s})} \cdot \mathrm{Ag}_{2} \mathrm{~S}_{(\mathrm{s})}$ was then filtered and rinsed with $\mathrm{MQ}-\mathrm{H}_{2} \mathrm{O}$ and $\mathrm{NH}_{4} \mathrm{OH}$. Samples were then dried and $\approx 3 \mathrm{mg}$ of $\mathrm{Ag}_{2} \mathrm{~S}_{(s)}$ was weighed into clean aluminium foil packets. Samples were then placed into nickel bombs which were subsequently pumped down to vacuum and then filled with $\mathrm{F}_{2(\mathrm{~g})}$ and heated to $\approx 250^{\circ} \mathrm{C}$ for $>8$ hours. $\mathrm{F}_{2(\mathrm{~g})}$ reacted with $\mathrm{Ag}_{2} \mathrm{~S}_{(\mathrm{s})}$ to produce $\mathrm{SF}_{6(\mathrm{~g})}$ which was then purified through a series of cold traps $\left(-196^{\circ} \mathrm{C}\right.$ and $\left.-120^{\circ} \mathrm{C}\right)$ and gas chromatography. Purified $\mathrm{SF}_{6(\mathrm{~g})}$ was then measured on a Thermo MAT-253 isotope ratio mass spectrometer set in dual-inlet mode. All results are presented on the V-CDT scale. Estimated total analytical uncertainty on the entire procedure is $<0.1 \%$ for $\delta^{34} S$ and $<0.01 \%$ for $\Delta^{33} S$ analyses. For full methods please refer to Crockford et al. (2019) and Kunzmann et al. (2017).

\section{Results}

The results of the sulphur isotope analysis of galena and pyrite, given in Table 4 and Fig. 15, show a large spread with $\delta^{34} \mathrm{~S}$ values ranging from $+12.3 \%$ to $-18.6 \%$. Sulphides in clasts exhibit higher $\delta^{34} \mathrm{~S}$

Table 4. Sulphur isotope data from the Vassbo sediments.

\begin{tabular}{lccccc}
\hline Sample ID & $\delta^{33} \mathrm{~S} \%$ & $\delta^{34} \mathrm{~S} \%$ & $\delta^{36} \mathrm{~S} \%$ & $\Delta^{33} \mathrm{~S} \%$ & $\Delta^{36} \mathrm{~S} \%$ \\
\hline $82-20-1$ BaSO4 & 11.775 & 23.048 & 44.32 & -0.029 & 0.07 \\
$82-20-2$ BaSO4 & 10.132 & 19.823 & 38.10 & -0.028 & 0.10 \\
$82-20-3$ BaSO4 & 11.905 & 23.282 & 44.80 & -0.018 & 0.10 \\
$82-21-1$ BaSO4 & 13.010 & 25.453 & 49.03 & -0.018 & 0.11 \\
$82-21-2$ BaSO4 & 11.995 & 23.522 & 45.77 & -0.050 & 0.61 \\
$82-19-1$ Py & -8.794 & -17.103 & -32.67 & 0.050 & -0.42 \\
$82-19-2$ PbS & 0.044 & 0.078 & 0.03 & 0.004 & -0.12 \\
$82-19-3$ PbS & -1.313 & -2.558 & -4.87 & 0.005 & -0.02 \\
$82-27-1$ PbS & 2.381 & 4.686 & 9.01 & -0.030 & 0.09 \\
$82-27-2$ Py & -7.932 & -15.411 & -29.46 & 0.034 & -0.39 \\
$82-27-3$ PbS & -5.268 & -10.268 & -19.70 & 0.033 & -0.28 \\
$82-27-4$ PbS & 1.957 & 3.842 & 7.40 & -0.019 & 0.09 \\
$82-27-5$ PbS & -2.620 & -5.065 & -9.51 & -0.008 & 0.09 \\
\hline
\end{tabular}




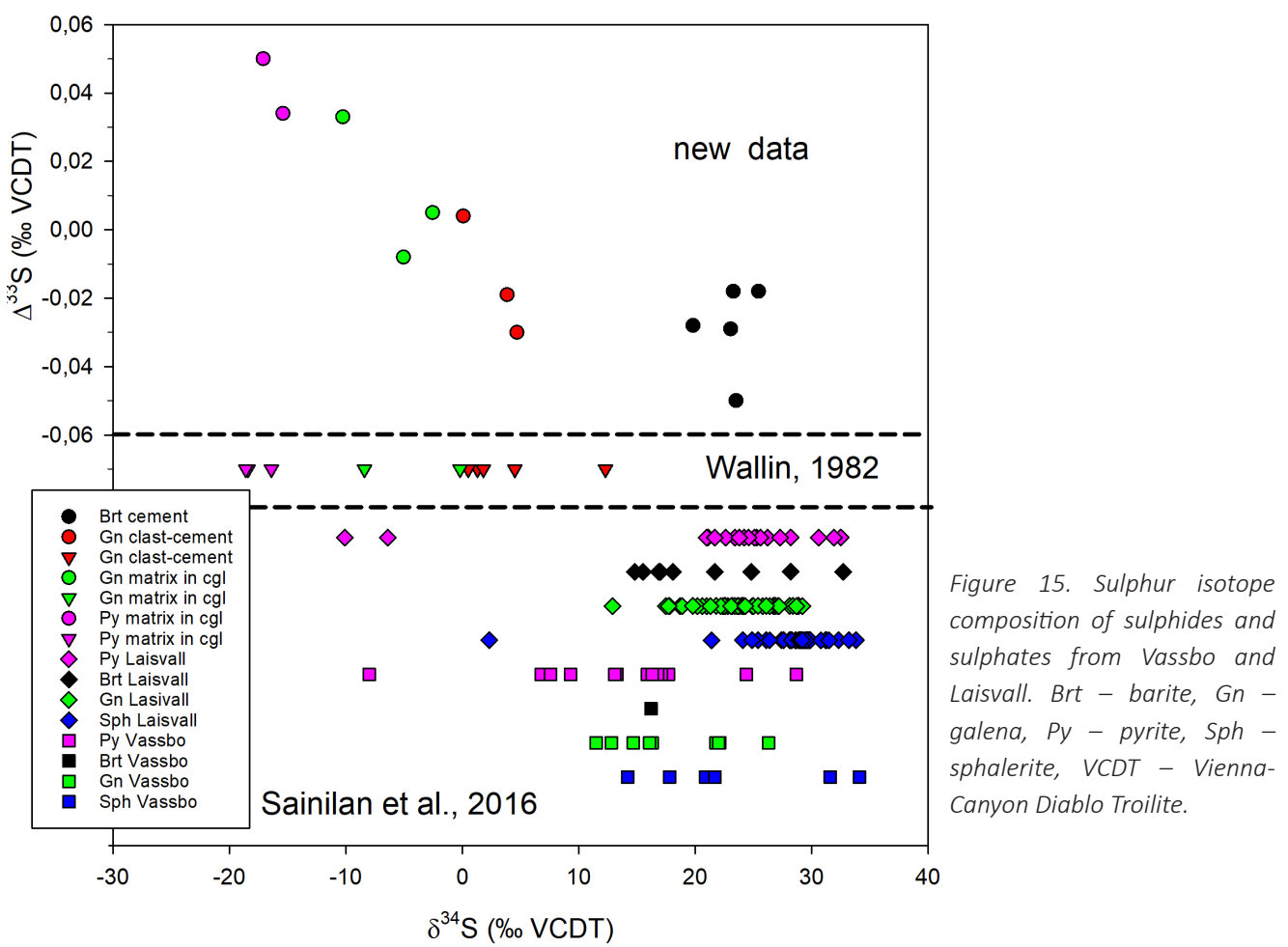

values compared to sulphides in the matrix. The pyrite in conglomerate matrix exhibits the lowest $\delta^{34} \mathrm{~S}$ values, between $-16.4 \%$ and $-18.6 \%$. The $\delta^{34} \mathrm{~S}$ values of galena and pyrite in the conglomerate are typically lower compared to galena and pyrite of the orebody in the underlying Gröveldalen Member (Fig. 15). The samples of the orebody that were analysed were from a medium- to coarsegrained light grey sandstone: this sandstone type is not represented among the clasts in the conglomerate.

The difference in the $S$ isotope composition of the galena in the clasts and in the matrix of the conglomerate was first published by Wallin (1989). Our new multiple $S$ isotope data of sulphides show a negative correlation between $\delta^{34} S$ and $\Delta^{33} S$ and converge towards the anticipated seawater sulphate composition that is broadly represented by the barite $S$ isotope composition (Fig 15 ). These $\mathrm{S}$ isotope relationships of sulphides and deviation from barite in conglomerate are consistent with sulphide precipitation under conditions of relatively open-system microbial sulphate reduction. Previously published $\mathrm{S}$ isotope results on ore-forming sulphides in the sandstone show typical $\delta^{34} \mathrm{~S}$ values broadly overlapping with barite. This indicates either high sulphate demand and precipitation in a closed environment or sulphide source from dissolving barite through thermochemical sulphate reduction at elevated temperature (Saintilan et al., 2016).

The Middle Cambrian transgression (Alum Shale Formation) resulted in reducing conditions on the seafloor and open access to seawater sulphate. This is reflected in the lighter sulphur isotope composition of the sulphides in the matrix of the conglomerate compared with the clasts. This open access to a reducing marine environment is also documented by frequent occurrences of framboidal pyrite (Fig. 12D) by Wallin (1989). 


\section{Discussion}

\section{Weathering of the Baltoscandian basement}

Schmitt (1999) estimated the $\mathrm{pH}$ of the Mid-Cretaceous rainwater to be around 5.5 and this indicates an even lower $\mathrm{pH}$ for the rainwater in the Early Cambrian. The high $\mathrm{CO}_{2}$ content must have resulted in a warm global climate at that time and much warmer than today. Evaporation on the tidal flats may have taken place, and the lack of thick fluvial sediments indicates an arid to semi-arid climate.

The weathering process of granitic rocks has recently been described by Goodfellow et al. (2016). They emphasise the importance of early weathering of biotite and the formation of ferrihydrite. They quantified the changes in chemistry, mineralogy, volumetric strain, tensile strength, connected porosity and hydraulic conductivity. The volume increase related to the precipitation of ferrihydrite is approximately $5 \%$, and it gave a significant increase in the porosity and in the hydraulic conductivity. The early breakdown of biotite may therefore initiate the break-down of other minerals such as apatite. The ferrihydrite has an exceptional capacity for adsorbing elements like $\mathrm{Pb}$, $\mathrm{Zn}, \mathrm{P}, \mathrm{Ba}$ and $\mathrm{Si}$ that are released during the weathering process (Eggelton, 2008). These are the same elements which dominate the cement in the ore-zone. Ferrihydrite is relatively soluble in groundwater compared with other $\mathrm{Fe}^{3+}$ minerals. A change in the groundwater composition (Eh and $\mathrm{pH}$ ) may also change the adsorption capacity (Cresswell \& Shand, 2008) or result in a dissolution/alteration of ferrihydrite, such that the adsorbed elements will be released in the groundwater.

The relationship between basement faults and ore is clearly documented by Saintilan et al. (2015a, b). It is, however, difficult to estimate the contribution of metals to the ore-forming process by weathering. Changes in hydraulic conductivity (Goodfellow et al., 2016) in the weathered faults may have played a significant role. Water rock interaction deeper in the basement may therefore have been more important for the ore-forming solution and better explain the transport of quartz together with metals and the content of noble gas and halogens (Kendrick et al., 2005)

\section{Source of lead and barium}

Lead isotopes have been used in many studies to find the source of lead in ore-forming processes. In the studies of the Osen deposit (Bjørlykke \& Thorpe, 1982; Bjørlykke et al., 2018), the underlying basement (Trysil granite) has been identified as the probable source of lead. In a granitic rock, the lead can either be hosted by feldspars (mainly potassic feldspar) with a low $\mathrm{U} / \mathrm{Pb}$ ratio or by minerals like biotite, hornblende and apatite with a higher $\mathrm{U} / \mathrm{Pb}$ ratio (Wedepohl, 1978). During weathering, there will first be a breakdown of iron-rich minerals (Goodfellow et al., 2016) with a relatively high U/Pb ratio giving a radiogenic $\mathrm{Pb}$ isotope composition of the groundwater. K-feldspar, which has a very low $\mathrm{U} / \mathrm{Pb}$, is resistant during weathering so that the release of lead will occur late in the weathering process. Differences in the $\mathrm{Pb}$ isotope composition between minerals are also dependent on time and in the case of Osen there is approximately $1 \mathrm{Ga}$ between the age of the Trysil Granite and the weathering process. In a granite that is considerably older than the weathering process, the lead in the biotite will be more radiogenic than the lead in the microcline (Bjørlykke et al., 2018). Most sandstone-hosted lead deposits have a similar $\mathrm{Pb} / \mathrm{Zn}$ ratios. Within each deposit there may, however, be large variations, and in the Vassbo mine there are areas where the zinc content is much higher than the lead content. Both in MVT and in sandstone-hosted lead deposit models $\mathrm{Pb}$ and $\mathrm{Zn}$ come from the same source (Bjørlykke \& Sangster, 1981; Leach et al., 2010). 
The $\mathrm{Pb}$ isotope compositions of SEDEX deposits are all non-radiogenic (Leach et al., 2010), indicating a different ore-forming process, compared to the sandstone-lead and MVT deposits. Alteration of K-feldspar during interaction with a brine with high $\mathrm{pH}$ and high $\mathrm{Na} / \mathrm{K}$ contents will produce albite and non-radiogenic lead will be released to the brine. The $\mathrm{Pb}$ isotope composition of the ore-forming solution will therefore reflect the non-radiogenic composition of the lead in the K-feldspar.

A study of the Osen deposit in Norway (Fig. 1) (Bjørlykke et al., 2018) concluded that the radiogenic $\mathrm{Pb}$ isotope composition was compatible with chemical weathering of the underlying Trysil granite. Minerals that weathered early, like biotite, have a higher U/Pb ratio compared with K-feldspar which weathers late. Using the whole-rock data and the $\mathrm{Pb}$ isotope compositions of the K-feldspar, we can conclude that the lead was released from the granite at around $540 \mathrm{Ma}$ ago (Fig. 14A).

The $\mathrm{Pb}$ isotope data of galena from Vassbo plot close to the $\mathrm{Pb}$ isotope composition of galena from the Osen deposit and on the same isochron. Because the ages of the basement in Vassbo and Osen are similar, the difference in isotope compositions may be explained by a slightly higher $\mathrm{U} / \mathrm{Pb}$ value in the basement at Vassbo. The $\mathrm{Pb}$ isotope compositions of barite from Vassbo are similar to those of the galena samples, indicating that $\mathrm{Ba}$ was part of the ore-forming solution and that it was released together with lead from the basement (Fig. 14B).

The basement source of lead and barium is also supported by noble gas and halogen data from Osen, Vassbo and Laisvall (Kendrick et al., 2005). They describe an extensive fluid basement interaction before mineralisation.

\section{Source of phosphorus}

In Vassbo, the laminated apatite cement occurs only in the sandstones of aeolian origin. There are, however, phosphorite clasts deposited in tidal channels and in the Hawke Bay conglomerate (aeolian sandstone clasts and matrix). The dark to black colour of the aeolian sandstone suggests a microbially mediated precipitation of laminated apatite around aeolian quartz grains (facies b, Wallin, 1982). The apatite content is low in the sandstone of facies a and apatite coating is not observed on the quartz grains. Tidal channels with clasts of sulphate (barite) and dark phosphorite/illite clasts with sphalerite indicate erosion of phosphorites from a lagoonal environment. Strontium isotope data from phosphorite in the Hawke Bay conglomerate (Saintilan et al., 2016) have a radiogenic ${ }^{87} \mathrm{Sr} /{ }^{86} \mathrm{Sr}$ ratio of $0.721016 \pm 14$, that has been interpreted to reflect a basement source of phosphorus at Vassbo.

A continental source of $\mathrm{P}$ has been assigned for layers and pebbles of apatite in the red, fluvial sandstone in the lower part of the Vangsås Formation (Vardal Member) at Ringsjøen, north of Gjøvik, southern Norway (Bjørlykke, 1979). The lack of vegetation on land in the early Cambrian resulted also in an extensive aeolian transport. Phosphatic beds in a tidal environment have been described (Drummond et al., 2008) from the Sete Lagoas formation in Brazil, and the authors suggest that the phosphorus was adsorbed on iron-hydroxide coatings of aeolian sand. 


\section{The ore formation in relation to the sedimentary processes}

The $\mathrm{Pb}$ isotope composition indicates that weathering and ferrihydrite played an important role in adsorbing elements like lead, barium and phosphorus. There are three sources of ferrihydrite in a near-shore environment.

- The weathering zone on the upper part of the Precambrian basement

- Aeolian sand

- Shear-zones or fault-zones combined with seismic pumping

The weathering of the Sub-Cambrian peneplain with the formation of hematite, probably initially ferrihydrite, related to fault structures has been described from southern Norway by Gabrielsen et al. $(2015,2018)$. An indication of seawater alteration is the presence of albite in the fault zones.

The most important factor for the ore formation is the marine transgression, which changed the chemistry in the aeolian sand, underlying weathering zones and in the fault-zones. Ferrihydrite became unstable and the adsorbed metals became released to brine that formed in the tidal zone.

Upon the submergence, the abundant phosphorus and iron in the aeolian sand promoted high microbial productivity, sulphate reduction and precipitation of lead, zinc and iron sulphides. At the same time, barite precipitation was confined to the upper parts of the redox gradient where sulphate was available. A lack of or the low number of burrowing animals in the Early Cambrian (Mascord, 2019) may explain the existence of shallow and sharp redox fronts near the surface in the tidal environment. Rapid changes in the sea-level may have shifted the precipitation fronts up and down.

Organic-rich clasts from tidal channels show early formation of disseminated sphalerite and veins with barite. The clasts with sphalerite indicate a mineralisation event before the tidal channel stage and the coating of galena on the clasts shows that the ore-forming process continued after the tidal erosion.

There is a later phase of ore formation with quartz and more coarse-grained sulphides. The solubility of quartz is temperature dependent and the presence of quartz together with galena and sphalerite indicates a higher temperature for the ore-forming fluids. This fluid is probably related to seismic pumping in the fault-zone/shear-zone.

The Hawke Bay conglomerate, with clasts of ore, represents an upper limit for the ore formation (Fig. 11A). Rounded clasts with ore mineral cement must have been lithified before the erosion of the Gröveldalen Member. The matrix of the conglomerate contains a lot of pyrite. Of special interest is the zoned pyrite on the surface of the clasts (Fig. 12A), which may be a sulphide alteration of iron-hydroxides to pyrite during the change from exposure to the atmosphere during the Hawke Bay Event to reducing conditions during deposition of the Alum Shale. $\mathrm{Pb}$ isotope data indicate that lead was released from the clasts in the conglomerate and later, together with phosphorus, adsorbed on the iron-hydroxides.

There is, on the other hand, a clear difference in the $\mathrm{S}$ isotope composition between the cement in the rounded clasts of aeolian sandstone and the matrix of the conglomerate. The matrix of the conglomerate also contains clasts of phosphorite, chert and framboidal pyrite. The occurrence of framboidal pyrite is consistent with open system sulphate reduction and the light sulphur isotope signature of the sulphides in the matrix. 


\section{The tectonic control of the ore-forming process}

The relationship between basement structures and the orientation of the Vassbo and Guttusjö deposits is well documented by Tegengren (1962) and Christofferson et al. (1979). Saintilan et al. (2015a) show, based on magnetic maps, the relationship between basement structures and the Laisvall and Vassbo lead-zinc deposits. The basement under the Guttusjöen and Vassbo deposits shows magnetic low anomalies, which indicate oxidation of magnetite (Fig. 5). Similar depletion of magnetite is found in dykes related to Permian fault zones in the Oslo Region (Olesen et al., 2006) where the magnetite has been oxidised down to 700 metres below the present-day surface. Dolerite dykes are usually more weathered than neighbouring granitic rocks.

The strong weathering of the dolerite is also reflected in depressions on the surface of the Precambrian basement, which can be several metres deep (Christofferson et al., 1979): this must have taken place before the early Cambrian marine transgression.

A major rifting phase took place on the Fennoscandian Shield in the Neoproterozoic and continued into the early Cambrian (Nystuen, 2008). In the northern part of Fennoscandia, the Timanian orogeny (Andresen et al., 2014) may have influenced large parts of the Fennoscandian Shield.

During the Hawke Bay Event, the maximum tectonic uplift was in the order of 100 metres (Nielsen \& Schovsbo, 2015) and the conglomerate can be found in large parts of the Baltoscandian Shield. Veins with lead-zinc from the Storuman district in northern Sweden have given an age of $531 \pm 6.5 \mathrm{Ma}$ (Billström et al., 2012) and may possibly also be related to the Timanide Orogen.

Neotectonic structures have been observed several places in Norway, and movement of groundwater is clearly related to seismic pumping in these structures (Olesen et al., 2004). Seismic pumping along the contact between a basement and overlying sediments has also been described by Li et al. (2017). In their study from California, Muir-Wood \& King (1993) calculated the water flow to be in the order of $0.5 \mathrm{~km}^{3}$ related to a period of earthquake activity. The water temperature is dependent on the depth to which the water reaches in the fault-zone or shear-zone. In the case of Vassbo we see no evidence of boiling and the temperature was probably below $100^{\circ} \mathrm{C}$.

The precipitation of quartz together with sulphides indicates a drop in temperature. Hydrocarbon in fluid inclusions (Saintilan et al., 2016) may indicate that a temperature of the hydrothermal solution of more than $65^{\circ} \mathrm{C}$ may have reacted with organic carbon formed by the phosphorus and iron in sediments with a supply of aeolian sand. The spread in fluid inclusion temperature from 100 to $200^{\circ} \mathrm{C}$ may cover the interval between ore formation and the maximum burial temperature.

Alternatively, the hydrocarbons can be formed at lower temperature by the release of hydrogen gas during earthquakes and the reaction between hydrogen gas and carbon-containing material (Zgonnik, 2020).

\section{Summary and conclusions}

The three main stages in the ore-forming process are shown in Fig. 16. The first stage is an extensive weathering of the Precambrian basement (Fig. 16A) including an upper alteration of feldspars and a deeper and more comprehensive alteration of biotite (Bjørlykke et al., 2018). Seismic pumping brought rainwater with oxygen into fault zones, which resulted in weathering and a breakdown of magnetite 


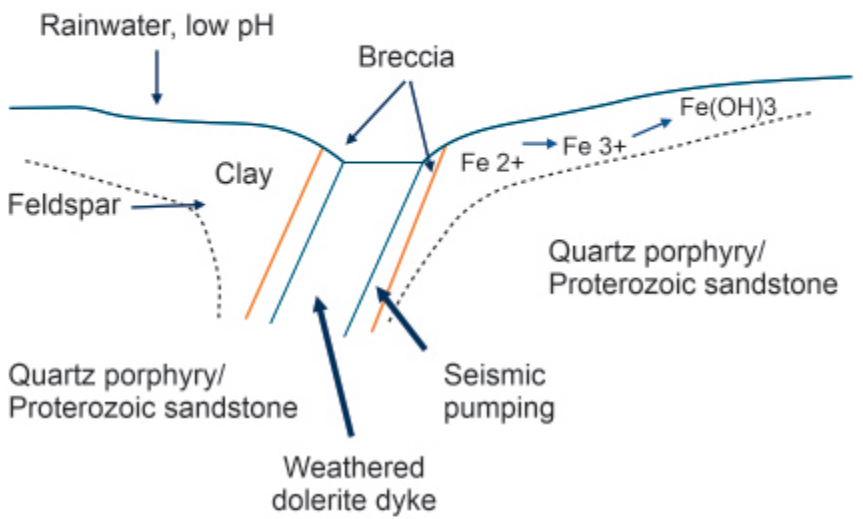

B

Vassbo after the marine transgression

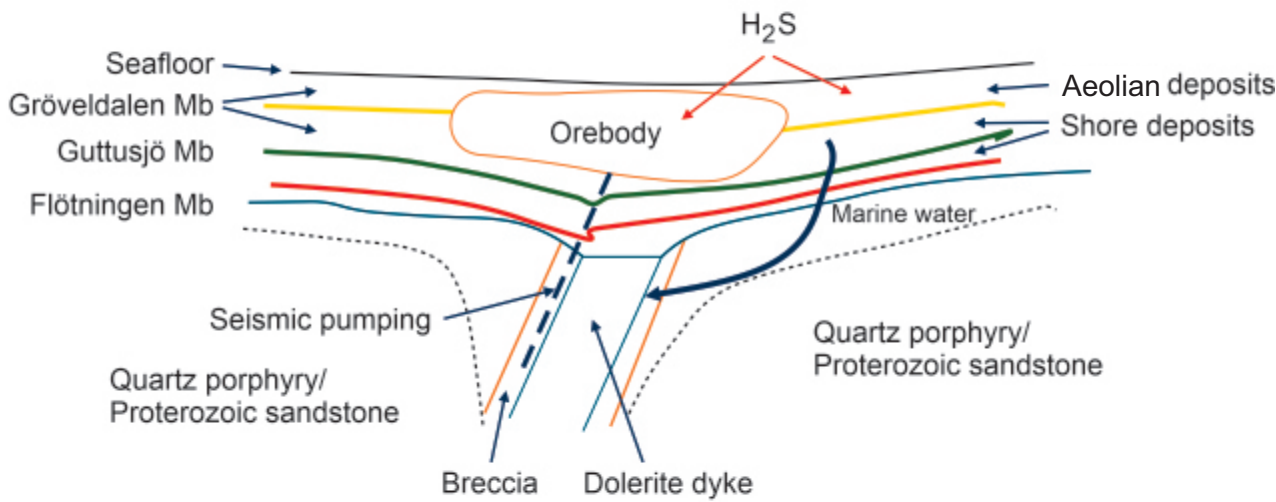

C Vassbo after the Hawke Bay Event

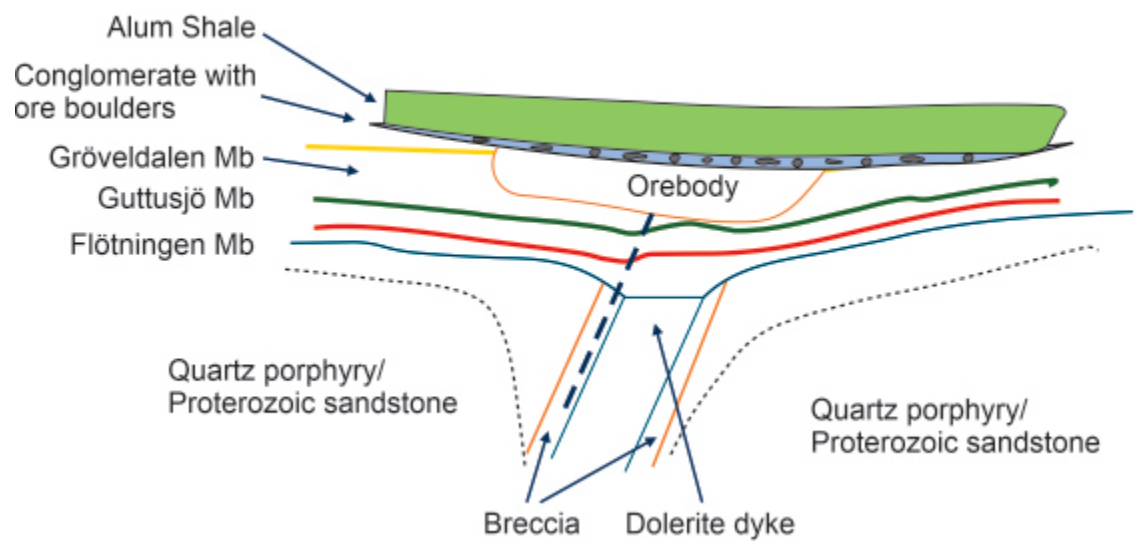

Figure 16. Summary of the ore formation at Vassbo in three steps. (A) Vassbo before the marine transgression (B) Vassbo after the marine transgression. (C) Vassbo after the Hawke Bay Event. 
deep into the basement. The magnetic map of the Vassbo area shows the clear relationship between the magnetite depletion, faults and orebodies. Microbial processes may have played a significant role in the weathering process (Goodfellow et al., 2016).

During the marine transgression (Fig. 16B), saline seawater penetrated into faults and shear zones, and alteration of the basement increased the salinity and the metal content in the water. Albite formed in the fractures close to the peneplain and indicates a marine connection (Gabrielsen et al., 2015).

There is a clear indication of an aeolian sand, coated with iron and phosphorus and organic carbon, especially in the lagoonal environment. We also see formation of early laminated apatite on quartz grains. Conglomerates with sulphides and phosphorite clasts are common in early Cambrian on the Baltoscandian Shield.

During seismic pumping, basement-sourced chloride-rich fluids were pumped into the permeable Gröveldalen Formation containing $\mathrm{H}_{2} \mathrm{~S}$ and galena, sphalerite and pyrite precipitated from the brine. The temperature of the ore-forming fluid was probably below $100^{\circ} \mathrm{C}$, which represents approximately 2-3 km depth in the basement. Hydrogen gas related to earthquakes may have formed hydrocarbons at lower temperatures (Zgonnik, 2020).

The ore-forming process resulted in a lithification of the sandstone and rounded clasts are found in the overlying Hawke Bay conglomerate on the border to the overlying Alum Shale. Textures at the surface of the clasts show that the cementation of the clasts including precipitation of galena and sphalerite took place before the erosion of the Gröveldalen sandstone during the Hawke Bay Event (Fig. 16C). The surfaces of the clasts are coated with pyrite which cuts the texture of the ore cement in the clasts. This is consistent with the $\mathrm{S}$ isotope compositions of the sulphides in the clasts, which are different from the composition of the pyrite coating around the clasts and in the matrix of the conglomerate. The $\mathrm{S}$ isotope composition of the matrix in the conglomerate has a light signature, indicating an open access to seawater sulphate, consistent with the framboidal pyrite in the matrix. The Hawke Bay Event (Fig. 16C) lasted for 6-7 myr (Nielsen \& Skovsbo, 2015).

Acknowledgements. We want to thank Boliden for access to the Vassbo mine with the open pit and the Guttusjö mine in 1980 and thank mine geologist S. Selkman for helping A. Bj. during the mine visit. We are grateful to T.H. Bui, P. Crockford and B. Wing for help with the sulphur isotope analyses at McGill University. I. Lundquist has made the drawings. Comments and corrections by the late R. Boyd have improved the English text. A. Nasuti photographed the samples. We also thank S. Strmic Palinkas and N. Schovsbo for their constructive and helpful reviews.

\section{References}

Andresen, A., Agyei-Dwarko, N.Y., Kristoffersen, M. \& Hanken, N.M. 2014: A Timanian foreland basin setting for the late Neoproterozoic-early Paleozoic cover sequence (Dividal Group) of northeastern Baltica. In Corfu, F., Gasser, D., \& Chew, D.M., (eds.): New perspectives on the Caledonides of Scandinavia and related areas, Geological Society, London, Special Publications 390, pp. 157-175. https://doi.org/10.1144/SP390.29.

Appello, C.A.J. \& Postma, D. 2005: Geochemistry, Groundwater and Pollution. $2^{\text {nd }}$ edition, Balkema, Leiden, 647 pp. 
Billström, K., Broman, C., Schneider, J., Pratt, W. \& Skogmo, G. 2012: Zn-Pb ores of Mississippi Valley-type in the Lycksele-Storuman district, Northern Sweden: A possible rift-related Cambrian mineralising event. Minerals 1, 169-207. https://doi.org/10.3390/min2030169.

Bjørlykke, A. 1979: Gjøvik og Dokka. Beskrivelse til de bergrunnsgeologiske kart 1816 I og 1816 IV (M:50 000). Norges geologiske Undersøkelse 344, 1-48.

Bjørlykke, A. \& Olesen, O. 2018: Caledonian deformation of the Precambrian basement in southeastern Norway. Norwegian Journal of Geology 98, 1-16. https://doi.org/10.17850/njg98-4-05.

Bjørlykke, A. \& Sangster, D.F. 1981: An overview of sandstone lead deposits and their relation to red-bed copper and carbonate-hosted lead-zinc deposits. In Skinner, B.J. (ed.): Seventy-Fifth Anniversary Volume, Society of Economic Geologists, Economic Geology Publishing Company, pp. 179-213. https://doi.org/10.5382/AV75.07.

Bjørlykke, A. \& Thorpe, R.I. 1982: The source of lead in the Osen sandstone lead deposit on the Baltic shield. Economic Geology 77, 430-440. https://doi.org/10.2113/gsecongeo.77.2.430.

Bjørlykke, A., Ihlen, P.M. \& Olerud, S. 1990: Metallogeny and lead isotope data from the Oslo Paleorift. Tectonophysics 178, 109-126. https://doi.org/10.1016/0040-1951(90)90462-H.

Bjørlykke, A., Sangster, D.F. \& Fehn, U. 1991: Relationship between high heat-producing (HHP) granites and stratabound lead-zinc deposits. In Pagel, M. \& Leroy J. L. (eds.): Source, Transport and Deposition of Metals: preceedings of the 25 years Society for Geology Applied to Mineral Deposits Anniversary Meeting, Nancy 30 August-3 September 1991, Balkema, Rotterdam, pp. 257-260.

Bjørlykke, A., Vokes, F.M., Birkeland, A. \& Thorpe, R.I. 1993: Lead Isotope Systematics of Strata-Bound Sulfide Deposits in the Caledonides of Norway. Economic Geology 88, 397-417. https://doi.org/10.2113/gsecongeo.88.2.397.

Bjørlykke, A., Bingen, B., Billström, K. \& Kooijman, E. 2018: The Sandstone-hosted Osen lead deposit, Norway: new $\mathrm{Pb}$ isotope evidence for sourcing in the underlying granitoid basement. Norwegian Journal of Geology 98, 1-12. https://doi.org/10.17850/njg98-4-04.

Canfield, D.E., Raiswell, R., Westrich, J.T., Reaves, C.M. \& Berner, R.A. 1986: The use of chromium reduction in the analysis of reduced inorganic sulfur in sediments and shales. Chemical geology 54, 149-155. https://doi.org/10.1016/0009-2541(86)90078-1.

Christofferson, H.C., Wallin, B., Selkman, S. \& Rickard, D.T. 1979: Mineralization controls in the sandstone lead-zinc deposit at Vassbo, Sweden. Economic Geology 74, 1239-1249. https://doi.org/10.2113/gsecongeo.74.5.1239.

Cresswell, R.G. \& Shand, P. 2008: Regolith and water. In Scott, K.M. \& Pain, C. (eds.): Regolith science, Commonwealth Scientific and Industrial Research Organization 2008, pp 251-280.

Crockford, P.W., Kunzmann, M., Bekker, A., Hayles, J., Bao, H., Halverson, G.P., Peng, Y., Bui, T.H., Cox, G.M., Gibson, T.M., Wörndle, S., Rainbird, R., Lepland, A., Swanson-Hysell, N.L., Master, S., Sreenivas, B., Kuznetsov, A., Krupenik, V.A. \& Wing, B.A. 2019: Claypool continued: Extending the isotopic record of sedimentary sulfate. Chemical Geology 513, 200-225. https://doi.org/10.1016/j.chemgeo.2019.02.030. 
Drummond, J.B.R., Pufahl, P.K., Porto, C.G. \& Carvalho, M. 2015: Neoproterozoic peritidal phoshorite from the Sete Lagoas Lagoas Formation (Brazil) and the Precambrian phosphorous cycle. Sedimentology 62, 1978-2008. https://doi.org/10.1111/sed.12214.

Eggleton, R.A. 2008: Regolith mineralogy. In Scott, K.M. \& Pain. C. (eds.): Regolith science, Commonwealth Scientific and Industrial Research Organization 2008, pp 45-72.

Fossen, H., Pedersen R.B., Bergh, S. \& Andresen, A. 2013: En fjellkjede blir til. In Ramberg, I.B., Bryhni, I., Nøttvedt, A. \& Ragnes, K. (eds.): Landet blir til-Norges geologi, $2^{\text {nd }}$ Edition, Trondheim, Norsk geologisk forening, $608 \mathrm{pp}$.

Gabrielsen, R.H., Nystuen, J.P., Jarsve, E.M. \& Lundmark, A.M. 2015: The Sub-Cambrian Peneplain in Southern Norway: its geological significance and its implications for post-Caledonian faulting, uplift and denudation. Journal of the Geological Society 172, 777-791. https://doi.org/10.1144/jgs2014-154.

Gabrielsen, R.H., Nystuen, J.P. \& Olesen, O. 2018: Fault distribution in the Precambrian basement of South Norway. Journal of Structural Geology 108, 269-289. https://doi.org/10.1016/j.jsg.2017.06.006.

Goodfellow, B.W., Hilley, G.E., Webb, S.M., Sklar, L.S., Moon, S. \& Olson, C.A. 2016: The chemical, mechanical, and hydrological evolution of weathering granitoid. Journal of Geophysical Research: Earth Surface 121, 1-26. https://doi.org/10.1002/2016JF003822.

Kendrick, M.A., Burgess, R., Harrison, D. \& Bjørlykke, A. 2005: Noble gas and halogen evidence for the origin of Scandinavian sandstone-hosted Pb-Zn deposits. Geochimica et Cosmochimica Acta 69, No 1, 109-129. https://doi.org/10.1016/j.gca.2004.05.045.

Kunzmann, M., Bui, T.H., Crockford, P.W., Halverson, G.P., Scott, C., Lyons, T.W. \& Wing, B.A. 2017: Bacterial sulfur disproportionation constrains timing of Neoproterozoic oxygenation. Geology 45, 207-210. https://doi.org/10.1130/G38602.1.

Ladenberger, A., Bèeri-Shlevin, Y., Claesson, S., Gee, D., Majka, J. \& Romanova, I.V. 2014: Tectonometamorphic evolution of the Åreskutan Nappe - Caledonian history revealed by SIMS U-Pb zircon geochronology. In Corfu, F., Gasser, D. \& Chew, D.M. (eds.): New Perspectives on the Caledonides of Scandinavia and Related Areas, Geological Society, London, Special Publications 390, 337-369. https://doi.org/10.1144/SP390.10.

Large, R.R., Mukherjee, I., Gregory, D.D., Steadman, J.A., Maslennikov, V.V. \& Meffre, S. 2017: Ocean and Atmosphere Geochemical Proxies Derived from Trace Elements in Marine Pyrite: Implications for Ore Genesis in Sedimentary Basins. Economic Geology 112, 423-450.

https://doi.org/10.2113/econgeo.112.2.423.

Leach, D.L., Bradley, D.C., Huston, D., Pisarevsky, S.A., Taylor, R.D. \& Gardoll, S.J. 2010: Sediment-hosted lead-zinc deposits in Earth history. Economic Geology 105, 593-625.

https://doi.org/10.2113/gsecongeo.105.3.593.

Li, Z., Chi, G., Bethune K.M., Thomas, D. \& Zaluski, G. 2017: Structural Controls on Fluid Flow During Compressional Reactivation of Basement Faults; Insights from Numerical Modelling for the Formation of Unconformity-Related Uranium deposits in the Athabasca Basin, Canada. Economic Geology 112, 451-466. https://doi.org/10.2113/econgeo.112.2.451. 
Mascord, M. 2019: The fossils of Bell Island. Geoscientist 29, 12-17.

https://doi.org/10.1144/geosci2019-009.

Muir-Wood, R. \& King, G.C.P. 1993: Hydrological Signatures of Earthquake Strain. Journal of Geophysical Research, Vol. 98, 22,035-22,068. https://doi.org/10.1029/93JB02219.

Nielsen, A.T. \& Schovsbo, N.H. 2011: The Lower Cambrian of Scandinavia: Depositional environment, sequence stratigraphy and paleogeography. Earth-Science Reviews 107, 207-310.

https://doi.org/10.1016/j.earscirev.2010.12.004.

Nielsen, A.T. \& Schovsbo, N.H. 2015: The regressive Early-Mid Cambrian "Hawke Bay Event" in Baltoscandia: Epeirorogenic uplift in concert with eustasy. Earth-Science Reviews 151, 288-350. https://doi.org/10.1016/j.earscirev.2015.09.012.

Nystuen, J.P. 2008: Break-up of the Precambrian continent, Late Precambrian, from Precambrian to Palozoic. In Ramberg, I.B., Bryhni, I., Nøttvedt, A. \& Ragnes, K. (eds.): The making of a land-Geology of Norway. Norwegian Geological Society, 120-147.

Olesen, O., Blikra, J.H., Braathen, A., Dehls, J.F., Olsen, L., Rise, L., Roberts, D., Riis, F., Faleide, J.I. \& Anda, E. 2004: Neotectonic deformation in Norway and its implications: a review. Norwegian Journal of Geology 84, 3-34.

Olesen, O., Dehls, J.F., Ebbing, J., Henriksen, H., Kihle, O. \& Lundin, E. 2006: Aeromagnetic mapping of the fracture zones in the Oslo Region - a new tool for improved planning of tunnels. Norwegian Journal of Geology 87, 253-267.

Rickard, D.T., Willdén, M.Y., Marinder, N.E. \& Donnelly, T.H. 1979: Studies on the genesis of the Laisvall sandstone lead-zinc deposits, Sweden. Economic Geology 74, 1255-1285. https://doi.org/10.2113/gsecongeo.74.5.1255.

Romer, R.L. 1992: Sandstone-hosted lead-zinc mineral deposits and their relation to the tectonic mobilization of the Baltic shield during the Caledonian orogeny-a reinterpretation. Mineralogy and Petrology 47, 67-85. https://doi.org/10.1007/BF01165298.

Saintilan, N.J., Stephens, M.B., Lundstam, E. \& Fontboté, L. 2015a: Control of Reactivated Basement Structures on Sandstone-Hosted Pb-Zn Deposits Along the Caledonian Front, Sweden: Evidence from Airborne Magnetic Data, Structural Analysis and Ore Grade Modeling. Economic Geology 110, 91-110. https://doi.org/10.2113/econgeo.110.1.91.

Saintilan, N.J., Schneider, J., Stephens, M.B., Chiaradia, M., Kouzmanov, K., Wälle, M. \& Fontboté, L. 2015b: A Middle Ordovician age for the Laisvall sandstone-hosted Pb-Zn deposit, Sweden: a response to early Caledonian orogenic activity. Economic Geology 110, 1779-1801.

https://doi.org/10.2113/econgeo.110.7.1779.

Saintilan, N.J., Spangenberg, J.E., Samankassou, E., Kauzmanov, K., Chiarada, M., Stephens, M.B. \& Fontbotè, L. 2016: A refined genetic model for the Laisvall and Vassbo Mississippi Valley-type sandstone-hosted deposits. Sweden: contsraints from paragenetic studies, organic geochemistry, and S, C, N and Sr isotope data. Mineralium Deposita 51, 639-664. https://doi.org/10.1007/s00126-015-0627-7. 
Schmitt, J.-M. 1999: Weathering, rainwater and atmosphere chemistry: example and modelling of granite weathering in present conditions, in a $\mathrm{CO}_{2}$-rich, and in an anoxic reducing atmosphere. International Association of Sedimentologists Special Publication 27, 21-41.

Skjeseth, S. 1963: Contributions to the geology of the Mjøsa District and the classical sparagmite area in Southern Norway. Norges geologiske undersøkelse 220, 1-126.

Snäll, S. 1988: Mineralogy and Maturity of the Alum Shales of South-Central Jämtland, Sweden. Sveriges geologiska undersökning, Serie C, Nr. 818, 1-46.

Söderlund, U., Karlsson, C., Johansson, L. \& Larsson, K. 2008: The Kullaberg peninsula - a glimpse of the Proterozoic evolution of SW Fennoscandia. Geologiska Föreningen i Stockholm Förhandlingar 130, 1-10. https://doi.org/10.1080/11035890801301001.

Tegengren, F.R. 1962. Vassbo blymalmsfyndigheteri Idre och dess geologiska inramning. Sveriges geologiska undersökning, Serie C, Nr. 586, 1-61.

Wallin, B. 1982: Sedimentology of the Lower Cambrian sequence at Vassbo, Sweden. Stockholm Contribution in Geology 39, 1-111.

Wallin, B. 1989: Origin of the Lower Cambrian phosphatic bed at Vassbo, Sweden. Terra Nova 1, 274-279. https://doi.org/10.1111/j.1365-3121.1989.tb00369.x.

Wedepohl, K.H. 1978: Handbook of geochemistry, vol. II/5. Springer Verlag, Berlin, Heidelberg, New York, 442 pp.

Welin, E. \& Lundquist, T. 1975: K-Ar ages of Jotnian dolerites dykes in Västernorrland County, Central Sweden. Geologiska Föreningen i Stockholm Förhandlingar 97, 83-88.

https://doi.org/10.1080/11035897509455475.

Zachrisson, E. 1980: Aspects of stratabound base metal mineralization in the Swedish Caledonides. Geological Survey of Irland Special Paper 5, 47-61.

Zgonnik, V. 2020: The occurrence and geoscience of natural hydrogen: A comprehensive review. Earth-Science Review 203, 103140. https://doi.org/10.1016/j.earscirev.2020.103140. 